\title{
Seasonal characteristics of fine particulate matter (PM) based on high-resolution time-of-flight aerosol mass spectrometric (HR-ToF-AMS) measurements at the HKUST Supersite in Hong Kong
}

\author{
Y. J. Li ${ }^{1, *}$, B. P. Lee ${ }^{1}$, L. Su ${ }^{2}$, J. C. H. Fung ${ }^{1,3}$, and C.K. Chan ${ }^{1,4}$ \\ ${ }^{1}$ Division of Environment, Hong Kong University of Science and Technology, Hong Kong, China \\ ${ }^{2}$ Environmental Science Program, Hong Kong University of Science and Technology, Hong Kong, China \\ ${ }^{3}$ Department of Mathematics, Hong Kong University of Science and Technology, Hong Kong, China \\ ${ }^{4}$ Department of Chemical and Biomolecular Engineering, Hong Kong University of Science and Technology, Hong Kong, \\ China \\ *now at: School of Engineering and Applied Sciences, Harvard University, Cambridge, MA, USA
}

Correspondence to: C. K. Chan (keckchan@ust.hk)

Received: 29 June 2014 - Published in Atmos. Chem. Phys. Discuss.: 8 August 2014

Revised: 22 November 2014 - Accepted: 24 November 2014 - Published: 7 January 2015

\begin{abstract}
Atmospheric particulate matter (PM) remains poorly understood due to the lack of comprehensive measurements at high time resolution for tracking its dynamic features and the lack of long-term observation for tracking its seasonal variability. Here, we present highly timeresolved and seasonal compositions and characteristics of non-refractory components in PM with a diameter less than $1 \mu \mathrm{m}\left(\mathrm{NR}-\mathrm{PM}_{1}\right)$ at a suburban site in Hong Kong. The measurements were made with an Aerodyne high-resolution time-of-flight aerosol mass spectrometer (HR-ToF-AMS) at the Hong Kong University of Science and Technology (HKUST) Air Quality Research Supersite for 4 months, with one in each season of the year. The average NR-PM 1 concentration of $\sim 15 \mu \mathrm{g} \mathrm{m}^{-3}$ is higher than those AMS measurements made in South Korea and Japan, but lower than those in North China, the Yangtze River Delta and the nearby Pearl River Delta. The seasonal dependence of the total NR$\mathrm{PM}_{1}$ monthly averaged concentrations was small, but that of the fractions of the species in NR-PM 1 was significant. Site characteristic plays an important role in the relative fractions of species in NR-PM 1 and our results are generally consistent with measurements at other non-urban sites in this regard. Detailed analyses were conducted on the AMS data in the aspects of (1) species concentrations, (2) size distributions, (3) degree of oxygenation of organics, and (4)
\end{abstract}

positive matrix factorization (PMF)-resolved organic factors in a seasonal context, as well as with air mass origin from back-trajectory analysis. Sulfate had the highest fraction in NR-PM $1>40 \%)$, and the surrogates of secondary organic species - semi-volatile oxygenated organic aerosol (SVOOA) and low-volatility oxygenated organic aerosol (LVOOA) - prevailed ( $~ 80 \%)$ in the organic portion of NR$\mathrm{PM}_{1}$. Local contributions to the organic portion of NR-PM at this suburban site was strongly dependent on season. The hydrocarbon-like organic aerosol (HOA) factor related to local traffic emissions contributed $>10 \%$ to organic aerosols in spring and summer but only 6-7\% in autumn and winter. The cooking organic aerosol (COA) factor contributed $>10 \%$ to organic aerosols in winter. With the aid of highly time-resolved data, diurnal patterns of the degree of oxygenation of organic aerosols were used to determine the sources and formation processes of the least understood organic portion of PM. The oxygen-to-carbon atomic ratio $(\mathrm{O}: \mathrm{C})$ and average carbon oxidation state $\left(\overline{\mathrm{OS}}_{\mathrm{C}}\right)$ showed little variation in autumn and winter, when the long-range transport of oxidized organics dominated, whereas they peaked in the afternoon in spring and summer, when locally produced secondary organic aerosol prevailed. Air mass origin, in contrast, had a strong influence on both NR-PM $\mathrm{P}_{1}$ concentrations and the fractions of species in NR-PM 1 . The findings of the 
current study provide a better understanding of the role of air mass origin in the seasonal characteristics of the PM composition and the relative importance of local vs. transported organic aerosols in this region.

\section{Introduction}

Particulate matter (PM) remains a serious air quality problem in megacities globally, and it is especially the case in the Pearl River Delta (PRD) economic region in South China (Chan and Yao, 2008; Huang et al., 2011), where Hong Kong lies on the southern coastal edge. To understand the PM characteristics, multiple intensive campaigns have been conducted in the PRD region (He et al., 2011; Huang et al., 2011; Xiao et al., 2011; Gong et al., 2012) and in Hong Kong (Lee et al., 2013; Li et al., 2013; Meng et al., 2014; Yeung et al., 2014). Most of these studies, however, were conducted in a particular season of the year and thus can only reflect the chemical characteristics of PM in that short period. In our previous studies at the HKUST Air Quality Research Supersite in spring 2011, PM at this suburban site was found to be influenced by both long-range transport during the hazy period (Lee et al., 2013) and local secondary production during the foggy periods, when the air was stagnant (Li et al., 2013). But these findings may not apply in the other seasons of the year because meteorological conditions vary from season to season. Thus high-time-resolution PM measurements should be made in different seasons to investigate the PM characteristics attributable to meteorological conditions. Hong Kong is influenced by long-range transport to even larger extents in other seasons than in spring, and the organic fractions in PM are higher especially in autumn and winter (Louie et al., 2005), although high PM episodes do not occur frequently (Huang et al., 2009). Aqueous-phase processing may also be less important in the other three seasons, when the relative humidity (RH) is much lower.

Both primary emission and secondary formation of PM may show seasonal variability. For example, coalcombustion organic aerosol is one of the major PM components in winter in cities in North China like Beijing (Sun et al., 2013). In contrast, secondary organic aerosols (SOA) are anticipated to be more dominant in summer, especially in subtropical areas like Hong Kong (Hu and Yu, 2013). Major air quality problems involving ozone and PM (Li et al., 2012; Wu et al., 2013) in the PRD are also strongly influenced by long-range transport.

In this study, we report NR-PM 1 (non-refractory components in PM with a diameter less than $1 \mu \mathrm{m}$ ) compositions and characteristics at the HKUST Air Quality Research Supersite in 4 months, with one in each season of the year. NR$\mathrm{PM}_{1}$ was measured with an Aerodyne high-resolution timeof-flight aerosol mass spectrometer (HR-ToF-AMS). Positive matrix factorization (PMF) was performed to resolve dif- ferent factors of organic aerosols. Seasonal characteristics of NR-PM ${ }_{1}$ including (1) species concentrations, (2) size distributions, (3) degree of oxygenation of organics, and (4) PMFresolved factors are presented. These characteristics are then discussed in conjunction with different air mass origins based on back-trajectory analysis. Finally, the influences of seasonality and air mass origin on NR-PM $\mathrm{PM}_{1}$ characteristics are discussed, along with the implications of assessing the longterm variability of such characteristics.

\section{Experimental}

\subsection{Site description}

The HKUST Supersite is located on the campus of HKUST, which sits on the hillside of Clear Water Bay on the east coast of Hong Kong (Lee et al., 2013; Li et al., 2013). Figure S1 in the Supplement shows the location of the sampling site in the PRD economic zone of South China. Both particle and gas measurements were taken at the HKUST Supersite using a number of online instruments (http://envr.ust.hk/research/ research-facility/background-materials.html). The supersite sits on the rooftop of a pump house on the seafront within a short distance (approximately $30 \mathrm{~m}$ ) of the sea. The sampling inlets were approximately $20 \mathrm{~m}$ a.s.l. There is little local emission around the site except for two minor sources. One is the Clear Water Bay Road just outside of the campus, which has mild traffic. The other is a small student canteen within $200 \mathrm{~m}$ of the site which operates only from 18:00 LT (local time) until midnight.

\subsection{Measurements}

NR-PM $\mathrm{PM}_{1}$ constituents including sulfate, nitrate, ammonium, chloride, and organics were measured with an Aerodyne HRToF-AMS operated under V-MS, pToF, and W-MS modes. The principle behind the instrument has been detailed elsewhere (DeCarlo et al., 2006) and a brief description is provided in Sects. 2 and 3 in the Supplement.

Gaseous species $\left(\mathrm{CO}, \mathrm{CO}_{2}, \mathrm{SO}_{2}, \mathrm{NO}, \mathrm{NO}_{2}\right.$, and $\left.\mathrm{O}_{3}\right)$ were measured with standard gas analyzers (Teledyne API). Meteorological parameters were measured by an automatic weather station mounted on a tower right next to the pump house on which the supersite sits. The sampling periods were 25 April to 1 June 2011 (spring), 1 September to 29 September 2011 (summer), 28 October to 15 December 2011 (autumn), and 19 January to 1 March 2012 (winter). Note that in this region, which has a monsoonal climate, prolonged summers and winters and brief autumns and springs are typical (Louie et al., 2005). The definition of seasons above is only approximate as different seasonal characteristics might still be observed within the same period. For example, the chemical composition and hygroscopicity of PM in the first half of September varied dramatically from those in the second half (Yeung et al., 2014), representing mainly summer character- 
istics but showing some transient behaviors toward autumn. For the current study, the majority of the sampling time was within the designated season and the seasonality can be captured.

\subsection{AMS data analysis}

The AMS unit-mass-resolution (UMR) data and the AMS high-resolution (HR) data were analyzed using the data analysis toolkit SQUIRREL 1.53F and PIKA 1.12F, respectively (Sueper, 2013). The data processing procedures have been detailed in previous studies (Allan et al., 2004; Aiken et al., 2007, 2008). A collection efficiency (CE) of 0.5, which has been widely used in field studies employing an AMS with a dryer installed in front of its particle inlet (Allan et al., 2003; Aiken et al., 2009), was applied during the whole campaign. Middlebrook et al. (2012) recently suggested that the CE should be composition-dependent with influences of (1) high nitrate content, (2) high relative humidity, and (3) high acidity, implying that the CE should depend on the phase state (liquid or solid) of the particles. In all 4 months, sulfate dominated the NR-PM $\mathrm{PM}_{1}$ mass, with only small amounts of nitrate (see Sect. 3.1 below). Figure S4 also shows that the aerosol particles were only slightly acidic. At this particular site, where the particles have an overwhelmingly dominant sulfate content (see discussion below), a CE of 0.5 would be more appropriate (Li et al., 2013).

Size distribution data are presented with the mass concentration $\left(\mathrm{d} M / \mathrm{d} \log D_{\text {va }}\right)$ as a function of vacuum aerodynamic diameter $\left(D_{\text {va }}\right)$. The median and mean distribution curves together with the range of the 75th percentile and the 25th percentile, i.e., the interquartile range (IQR), are shown for size distributions in the periods of interest (see Sect. 3.2 below). The size distributions were as measured and not normalized to average mass concentrations from $\mathrm{V}$ mode.

Elemental analysis (Aiken et al., 2007, 2008) was performed for organics with HR data to obtain the oxygen-tocarbon atomic ratio $(\mathrm{O}: \mathrm{C})$, the hydrogen-to-carbon atomic ratio $(\mathrm{H}: \mathrm{C})$, and the ratio of organic matter to organic carbon $(\mathrm{OM} / \mathrm{OC})$. We reflect the degree of oxygenation of organics in two ways. The first is the $\mathrm{O}: \mathrm{C}$ directly from elemental analysis (Aiken et al., 2007, 2008) and the second is the average carbon oxidation state $\left(\overline{\mathrm{OS}}_{\mathrm{C}}\right)$, which can be approximated by $2 \times \mathrm{O}: \mathrm{C}-\mathrm{H}: \mathrm{C}$ (Kroll et al., 2011).

\subsection{Positive matrix factorization (PMF) analysis}

HR mass spectra of organic components were analyzed by means of PMF (Paatero and Tapper, 1994; Lanz et al., 2007; Zhang et al., 2011) with a toolkit (version 2.06) based on Igor Pro (Ulbrich et al., 2009). The procedures for PMF analysis using AMS data have been presented elsewhere (Ulbrich et al., 2009; Zhang et al., 2011). In this study, HR mass spectra $(m / z$ 12-150) were used as input for PMF separately for each month, with the error matrix estimated from the sum of elec- tronic and Poisson ion-counting errors for relevant HR ion fragments (Allan et al., 2003; Ulbrich et al., 2009). "Bad" ions with a signal-to-noise ratio (SNR) $<0.2$ were removed, while "weak" ions $(0.2<\mathrm{SNR}<2)$ were down-weighted by a factor of 2. Ions $\left(\mathrm{O}^{+}, \mathrm{HO}^{+}, \mathrm{H}_{2} \mathrm{O}^{+}, \mathrm{CO}^{+}\right.$, and $\left.\mathrm{CO}_{2}^{+}\right)$with duplicated information related to the ion $\mathrm{CO}_{2}^{+}$were further down-weighted by a factor equal to the square root of the number of related ions. PMF was first run under the "exploration" mode with the seed value varying from 0 to 100 in steps of 5 (Ulbrich et al., 2009; Zhang et al., 2011). No local minima were shown for the $Q / Q_{\exp }$ value, which indicates the results were insensitive to the choice of the seed value. Therefore, further analysis was proceeded with a seed value of 0 for all months. Then PMF was run with fPeak varying from -1 to 1 in steps of 0.1 for $p$ (number of factors) from 1 to 10 . Solutions with seven to eight factors were chosen to minimize residuals and $Q$ values and to resolve a known factor from cooking. Some of those factors were then combined to produce four-factor solutions based on comparison with mass spectra from the literature and a time series of external tracers. The details of the factor combination are shown in the Supplement (Sect. 5). A four-factor solution, with hydrocarbon-like organic aerosols (HOA), cooking organic aerosols (COA), semi-volatile oxygenated organic aerosols (SVOOA), and low-volatility oxygenated organic aerosols (LVOOA), was adopted. The first two factors are considered as locally emitted primary organic aerosols (POA), while the latter two are surrogates of SOA (Jimenez et al., 2009).

\subsection{Back-trajectory analysis}

In this study, $72 \mathrm{~h}$ back trajectories were calculated every hour using version 4.8 of the Hybrid Single-Particle Lagrangian Integrated Trajectory (HYSPLIT) model (Draxler and Hess, 1997; Draxler et al., 2012a) for the four sampling periods from 2011 to 2012. The ending location for the trajectories was the HKUST Supersite (latitude: $22.337^{\circ} \mathrm{N}$; longitude: $114.263^{\circ} \mathrm{E}$ ) at an elevation of $300 \mathrm{~m}$ or $500 \mathrm{~m}$ a.g.l. The hourly output data of the Weather Research and Forecasting (WRF) model (Wang et al., 2014) were used to drive the HYSPLIT model. When the WRF simulations are finished, the necessary parameters, including 14 surface and 5 upper-level variables, are extracted from hourly WRF outputs and converted into the compatible format for HYSPLIT (Draxler et al., 2012b). The grid resolution of WRF simulation was $27 \mathrm{~km}$ and the total number of vertical layers was 39 , with the top level pressure being $50 \mathrm{mb}$, and 4-D data assimilation (FDDA) was applied to the simulation domain to minimize integration errors. To identify the pollutant characteristics in different predominant transport patterns, back trajectories were clustered into groups with similar patterns. The groups, called clusters hereafter, are represented by their mean trajectories (Draxler et al., 2012b).

The solutions with the arrival heights of 300 and $500 \mathrm{~m}$ and with 4, 5, and 6 clusters (Fig. S19) were evaluated using four 
Table 1. Percentages of time split among the five clusters (300 m, five-cluster solution) in each season.

\begin{tabular}{lrrrrrr}
\hline Season & 1 & 2 & 3 & 4 & Total \\
\cline { 2 - 6 } & \multicolumn{9}{c}{ Cluster } & 5 \\
\cline { 2 - 7 } & Marine - east & Coastal & Local & Marine - south & Continental \\
\hline May 2011, spr. & 15.6 & 22.4 & 26.7 & 34.5 & 0.8 & 100 \\
Sep 2011, sum. & 34.0 & 29.5 & 15.5 & 17.4 & 0.8 & 97 \\
Nov 2011, aut. & 19.2 & 41.6 & 16.5 & 2.2 & 20.4 & 100 \\
Feb 2012, win. & 8.9 & 46.1 & 36.0 & 2.8 & 6.1 & 100 \\
\hline
\end{tabular}

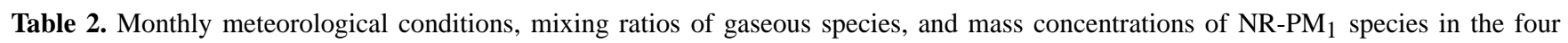
measurement periods.

\begin{tabular}{|c|c|c|c|c|c|c|c|c|c|}
\hline & & \multicolumn{2}{|c|}{ Spring: May $2011^{a}$} & \multicolumn{2}{|c|}{ Summer: Sep 2011} & \multicolumn{2}{|c|}{ Autumn: Nov 2011} & \multicolumn{2}{|c|}{ Winter: Feb 2012} \\
\hline & & $\operatorname{avg} \pm \mathrm{SD}^{\mathrm{e}}$ & $50 \% \frac{75 \%}{25 \%}$ & $\operatorname{avg} \pm \mathrm{SD}$ & $50 \% \frac{75 \%}{25 \%}$ & $\operatorname{avg} \pm \mathrm{SD}$ & $50 \% \frac{75 \%}{25 \%}$ & $\operatorname{avg} \pm \mathrm{SD}$ & $50 \% \frac{75 \%}{25 \%}$ \\
\hline \multirow[t]{3}{*}{ Met. $^{b}$} & $T\left({ }^{\circ} \mathrm{C}\right)$ & $24.3 \pm 4.0$ & $24.8_{23.1}^{26.3}$ & $27.9 \pm 1.9$ & $28.1_{26.5}^{29.0}$ & $21.2 \pm 3.9$ & $21.7_{19.2}^{24.0}$ & $14.5 \pm 2.8$ & $14.7_{12.7}^{16.3}$ \\
\hline & $\mathrm{RH}(\%)$ & $80.3 \pm 10.6$ & $82.7_{75.1}^{88.2}$ & $78.3 \pm 7.6$ & $79.2_{72.9}^{83.9}$ & $72.7 \pm 12.1$ & $73.6_{64.8}^{82.2}$ & $84.0 \pm 8.8$ & $84.8_{79.1}^{90.2}$ \\
\hline & ws $\left(\mathrm{m} \mathrm{s}^{-1}\right)$ & $1.4 \pm 1.0$ & $1.3_{0.7}^{2.0}$ & $2.1 \pm 1.2$ & $1.9_{1.3}^{2.8}$ & $2.3 \pm 1.5$ & $1.9_{1.2}^{2.9}$ & $1.7 \pm 1.2$ & $1.5_{0.8}^{2.5}$ \\
\hline \multirow{4}{*}{$\begin{array}{l}\mathrm{Gas}^{\mathrm{c}} \\
(\mathrm{ppbv})\end{array}$} & $\mathrm{CO}$ & $381 \pm 226$ & $378_{200}^{494}$ & $302 \pm 117$ & $286_{203}^{386}$ & $314 \pm 170$ & $287_{189}^{400}$ & $438 \pm 167$ & $420_{318}^{540}$ \\
\hline & $\mathrm{NO}_{\mathrm{x}}$ & $11.0 \pm 11.4$ & $7.5_{5.0}^{12.6}$ & $6.1 \pm 5.9$ & $4.6_{3.2}^{7.0}$ & $6.3 \pm 5.1$ & $5.0_{3.3}^{7.6}$ & $8.6 \pm 10.2$ & $6.6_{4.5}^{9.6}$ \\
\hline & $\mathrm{SO}_{2}$ & $1.8 \pm 1.6$ & $1.4_{0.9}^{2.1}$ & $2.1 \pm 1.3$ & $1.8_{1.1}^{2.7}$ & $3.4 \pm 1.8$ & $3.0_{2.1}^{4.2}$ & $1.6 \pm 1.1$ & $1.3_{0.8}^{2.0}$ \\
\hline & $\mathrm{O}_{\mathrm{x}}$ & $45.2 \pm 26.2$ & $37.6_{26.3}^{59.1}$ & $48.4 \pm 15.3$ & 47.958 .0 & $49.8 \pm 18.3$ & $48.1_{35.4}^{62.1}$ & $37.3 \pm 13.2$ & $36.5_{26.8}^{46.2}$ \\
\hline \multirow{6}{*}{$\begin{array}{l}\text { NR-PM } \\
\left(\mu \mathrm{g} \mathrm{m}^{3}\right)^{d}\end{array}$} & $\mathrm{SO}_{4}^{2-}$ & $7.4 \pm 4.5$ & $6.7_{4.1}^{9.7}$ & $8.7 \pm 3.8$ & $8.9_{5.9}^{11.4}$ & $7.1 \pm 3.7$ & $6.6_{4.6}^{9.7}$ & $6.2 \pm 3.2$ & $5.8_{4.1}^{7.6}$ \\
\hline & $\mathrm{NO}_{3}^{-}$ & $0.6 \pm 0.7$ & $0.4_{0.2}^{0.6}$ & $0.4 \pm 0.4$ & $0.2_{0.1}^{0.5}$ & $0.7 \pm 0.5$ & $0.5_{0.3}^{0.9}$ & $1.6 \pm 1.4$ & $1.1_{0.6}^{2.1}$ \\
\hline & $\mathrm{NH}_{4}^{+}$ & $2.3 \pm 1.4$ & $2.1_{1.3}^{3.2}$ & $2.4 \pm 1.0$ & $2.4_{1.7}^{3.2}$ & $2.1 \pm 1.1$ & $2.0_{1.4}^{2.8}$ & $2.4 \pm 1.2$ & $2.3_{1.7}^{2.8}$ \\
\hline & $\mathrm{Cl}^{-}$ & $0.02 \pm 0.02$ & $0.01_{<\mathrm{CDL}}^{0.02}$ & $0.01 \pm 0.01$ & $0.01_{0.01}^{0.02}$ & $0.02 \pm 0.02$ & $0.01_{0.01}^{0.02}$ & $0.13 \pm 0.18$ & $0.07_{0.03}^{0.2}$ \\
\hline & Org & $4.0 \pm 3.3$ & $3.2_{1.8}^{5.2}$ & $4.1 \pm 3.1$ & $3.0_{1.6}^{6.5}$ & $6.0 \pm 3.5$ & $5.3_{3.5}^{8.1}$ & $5.1 \pm 2.8$ & $4.7_{3.2}^{6.4}$ \\
\hline & $\mathrm{NR}-\mathrm{PM}_{1}$ & $14.3 \pm 3.0$ & $12.7_{7.7^{19.7}}$ & $15.6 \pm 2.6$ & $15.4_{10.7}^{20.8}$ & $15.9 \pm 2.7$ & $14.7_{10.3}^{21.6}$ & $15.4 \pm 2.1$ & $14.5_{10.8}^{18.2}$ \\
\hline
\end{tabular}

different species concentrations as indicators of (a) transported species (sulfate and LVOOA) and (b) locally emitted species (HOA and COA). The concentrations of these four species in each cluster in a solution are plotted in boxand-whisker plots in Figs. S20 and S21. The rationale is as follows: (1) a larger number of clusters can potentially provide more information and should be attempted; (2) too many clusters may be purely mathematical and makes little physical sense, and thus should be avoided; (3) transported species with anthropogenic origins should be associated with long trajectories from the continent; and (4) locally emitted species should be associated with short trajectories with calm wind. The optimal number of clusters balancing the first and second points was chosen and an evaluation of the third and fourth points for the same arrival height was conducted to support the choice. More details about the evaluation are shown in the Supplement (Sect. 6). Based on the evaluation, a solution of five clusters with arrival height of $300 \mathrm{~m}$ was adopted and was used for further discussion. Figure S22 shows the individual trajectory in each month with trajectories in each cluster color-coded for the $300 \mathrm{~m}$ arrival height and five-cluster solution. Table 1 shows the percentages of time in each measurement month that belong to one of the five clusters. 


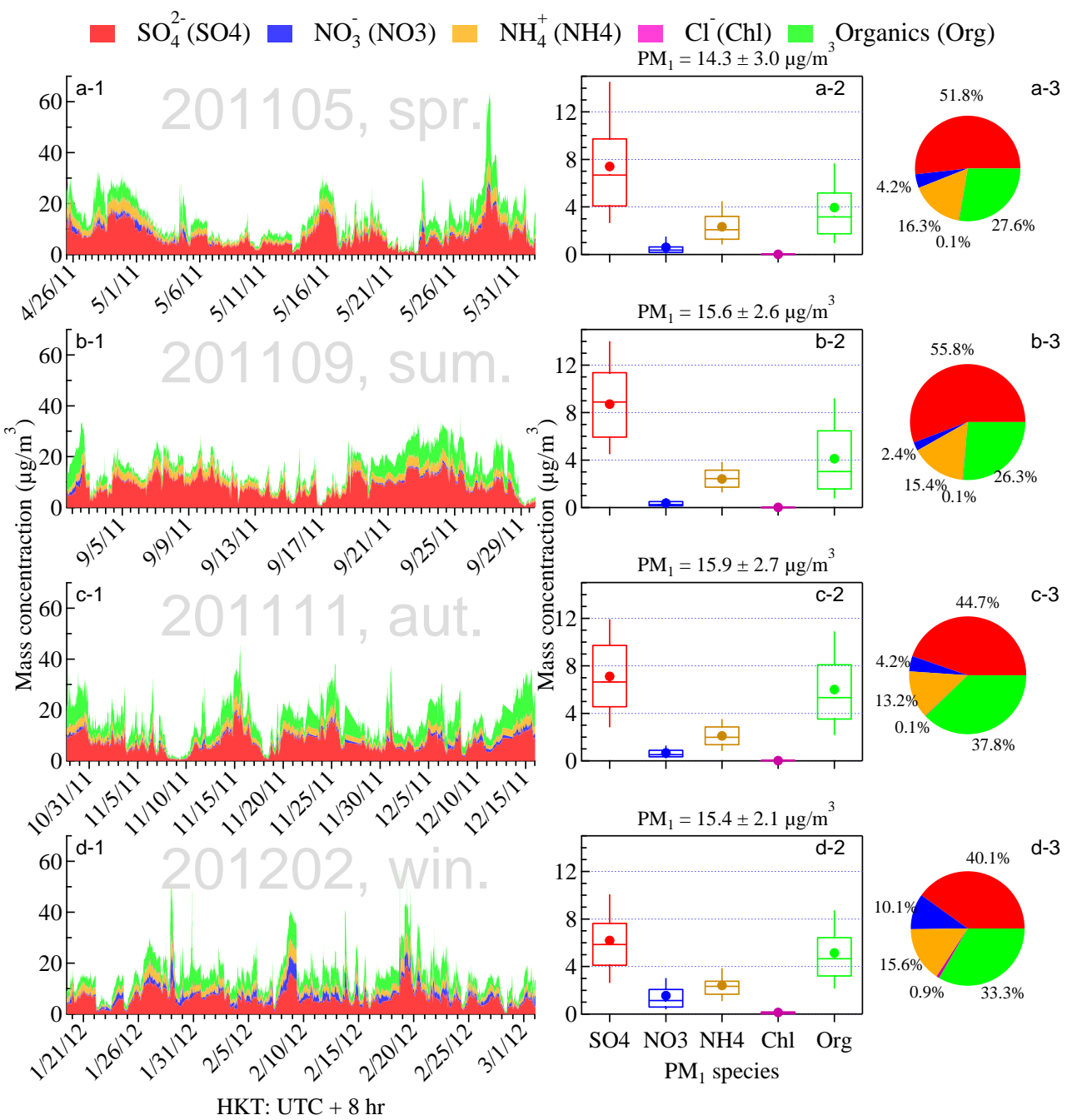

Figure 1. Summary of species (sulfate, nitrate, ammonium, chloride, and organics) in NR-PM 1 in the 4 months. $x-1$ : time series; $x-2$ : monthly mean (dot), median (bar), 25 and $75 \%$ percentiles (box), and 10 and $90 \%$ percentiles (whiskers), and x-3: monthly fraction (x-3), where " $x$ " is "a" for spring (May 2011), "b" for summer (September 2011), "c" for autumn (November 2011), and "d" for winter (February 2012). Monthly averaged total NR-PM 1 concentrations are shown above the $\mathrm{x}-2$ panels with 1 standard deviation. The area of a pie chart is proportional to the NR-PM 1 concentration.

\section{Results and discussion}

\subsection{Overall characteristics}

Here we first discuss the overall characteristics of NR-PM 1 in different seasons. Figure 1 shows the time series, monthly average concentrations, and percentages of the five species (sulfate, nitrate, ammonium, chloride, and organics) measured by the HR-ToF-AMS. The total NR-PM 1 concentration showed little seasonal variation, with monthly averages ranging from 14.3 to $15.9 \mathrm{\mu g} \mathrm{m}^{-3}$. In contrast, the fractions of each species were quite different in the four seasons. Sulfate had the highest portion in NR-PM $\mathrm{N}_{1}$ for all four seasons, accounting for $40-56 \%$ by mass. Nitrate remained low $(<5 \%)$ in spring, summer, and autumn, but it went up to $10 \%$ of NR-PM $\mathrm{PM}_{1}$ mass in winter. Ammonium accounted for $13-16 \%$ of NR-PM mass. The chloride fraction remained very small in all four seasons, but also went up to $\sim 1 \%$ in winter (compared with just $\sim 0.1 \%$ in the other three seasons), with a seasonal variability similar to that of nitrate. The contribution of organics varied from $26 \%$ in summer to $38 \%$ in autumn. Although they still contributed less than sulfate did, organics had quite comparable concentrations to sulfate in autumn and winter.

Table 2 shows the averages and standard deviations as well as the 50th, 25th, and 75th percentiles of meteorological parameters (temperature, $\mathrm{RH}$, and wind speed), gaseous species $\left(\mathrm{CO}, \mathrm{NO}_{\mathrm{x}}=\mathrm{NO}+\mathrm{NO}_{2}, \mathrm{SO}_{2}, \mathrm{O}_{\mathrm{x}}=\mathrm{O}_{3}+\mathrm{NO}_{2}\right)$, and NR-PM ${ }_{1}$ species. Winter was the only season with average temperature below $20^{\circ} \mathrm{C}$. The observation of high nitrate and chloride concentrations in winter is thus in line with the gas- 
Red: sulfate. Blue: nitrate. Brown: ammonium. Green: organics.Within the green outline: Grey: POA. Light red: OOA.

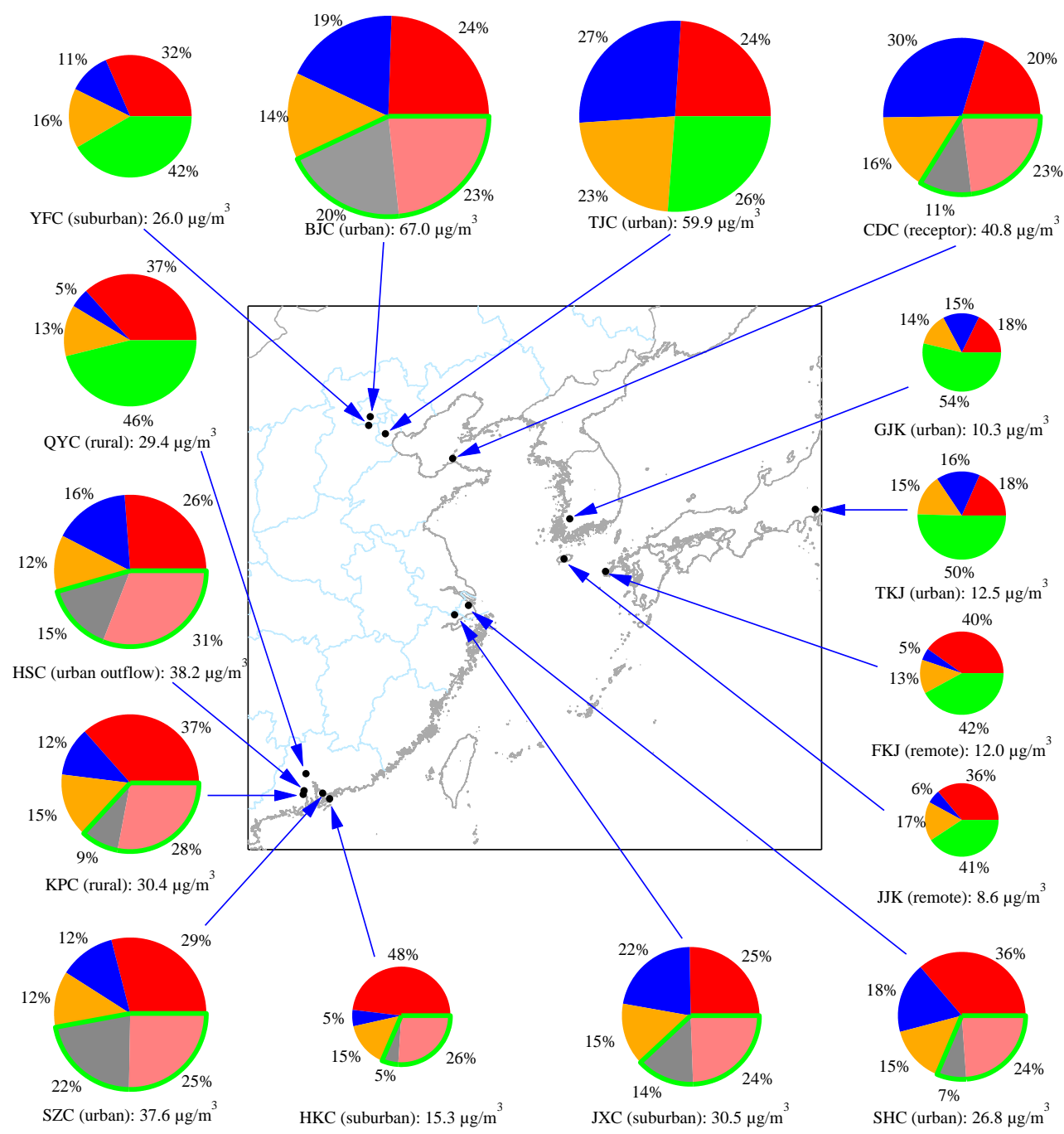

Figure 2. Summary of AMS-measured NR-PM 1 compositions in Asia. The green slices represent total organics. Within the green outlines are organics with PMF-resolved factors. The grey slices within the green outlines are the sum of all POA with one or more factors of HOA, COA, BBOA, and CCOA (coal combustion). The light red slices within the green outlines are the sum of all OOAs with one or more factors of SVOOA and LVOOA. The area of a pie chart is proportional to the NR-PM 1 concentration. See Table S2 in the Supplement for the site locations.

particle partitioning behavior of ammonium nitrate and ammonium chloride, whose formations are favored at low temperatures (Seinfeld and Pandis, 2006). Wind speed was the lowest in spring, which enabled local pollutants such as those from traffic and cooking to accumulate. Together with the high humidity and relatively low temperature, the low wind speed also promotes fog formation and aqueous-phase chemistry ( $\mathrm{Li}$ et al., 2013). CO had the highest concentration in winter and the lowest in summer, a clear indicator of seasonal patterns of air mass origins. Hong Kong is dominated by air masses from the ocean with few anthropogenic sources in summer, while it is mostly under the influence of air masses from the north with large combustion-related sources in win- ter (Yuan et al., 2006). $\mathrm{NO}_{\mathrm{x}}$ had the highest concentration in spring, indicating strongest traffic-related influence (Lau et al., 2008) in the season. $\mathrm{SO}_{2}$ had the highest concentration in autumn, but surprisingly the lowest in winter. $\mathrm{O}_{\mathrm{x}}$ had the highest concentrations in autumn and summer, probably because of relatively high photochemical activities in these two seasons.

Apart from temporal variations in PM concentration and composition, spatial heterogeneity of PM is also an important aspect for understanding the air pollution of a region. For example, Zhang et al. (2012) compared $\mathrm{PM}_{10}$ compositions in 16 sites in various regions in China and their relationship with visibility reduction and identified four major haze areas 
Medians Means Spr., 201105
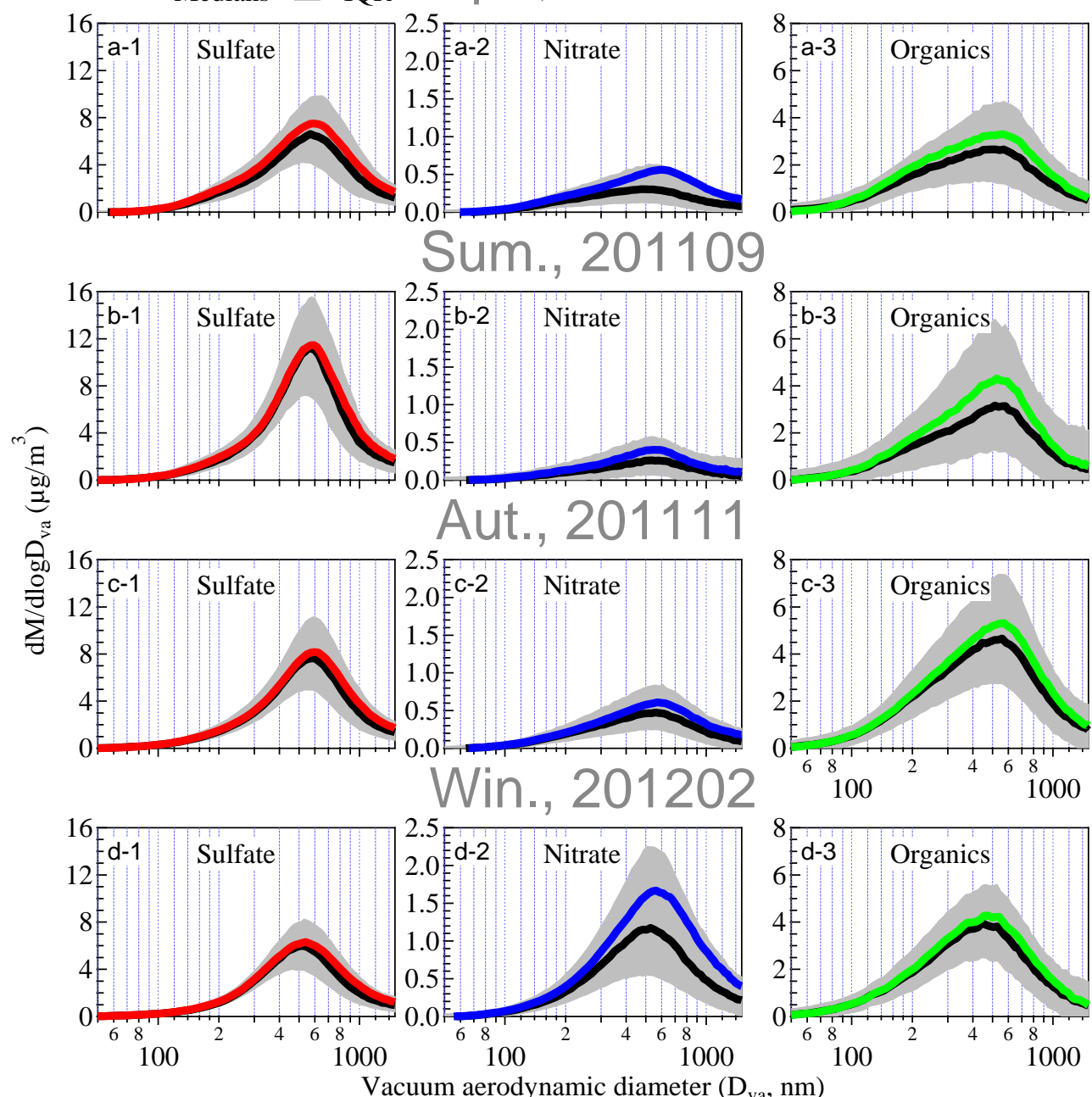

Figure 3. Size distributions of sulfate $\left(\mathrm{SO}_{4}\right)$, nitrate $\left(\mathrm{NO}_{3}\right)$, and organics $(\mathrm{Org})$ in the 4 months. The red, blue, and green lines are the means; the black lines are the medians; and the grey areas are the interquartile ranges (IQRs).

that coincided with the fast economic development therein. Yang et al. (2011) summarized chemical species measured in $\mathrm{PM}_{2.5}$ in China and concluded that the $\mathrm{PM}_{2.5}$ concentration not only varied by a factor of 6 but the percentages of individual species were also substantially different at different sites (e.g., urban vs. rural) and even among the four representative megacities. Herein, we put our four-season averages of sulfate, ammonium, nitrate, and organics (SANO) concentrations in NR-PM ${ }_{1}$ in comparison with other available AMS measurements in Asia from the literature, as shown in Fig. 2. Overall, there is a paucity of AMS measurements in China, given its large geographical coverage and the variability of air pollution and their causes in different cities. This study provides a comprehensive analysis in seasonal characteristics of NR-PM 1 compared to other AMS measurements in this region. For clarity, chloride is excluded from this discussion because its concentration is quite low $(<5 \%)$ in most of the AMS measurements. The data from the literature and details of the measurements are shown in Table S2. SANO concentrations measured in multiple sites in South Korea and Japan were less than $15 \mu \mathrm{g} \mathrm{m}^{-3}$, while those measured in North China normally exceeded $40 \mu \mathrm{g} \mathrm{m}^{-3}$. The highest concentration was found in Beijing, and it was an average from five separate measurement campaigns covering a few urban sites and including the strongest episodic event in January 2013 (Zhang et al., 2014). Two measurements in the Yangtze River Delta (YRD) showed SANO concentrations of higher than $25 \mu \mathrm{g} \mathrm{m}^{-3}$. Multiple measurements in the PRD region showed SANO concentrations ranging from 30 to $40 \mu \mathrm{g} \mathrm{m}^{-3}$. Our suburban site in Hong Kong, as reported in this study, has an average SANO concentration of $15.3 \mu \mathrm{g} \mathrm{m}^{-3}$. In terms of mass fractions, urban sites (such as Shenzhen, SZC) or sites downwind of urban areas (such as Heshan, HSC) have higher organic and nitrate fractions, while those remote and 


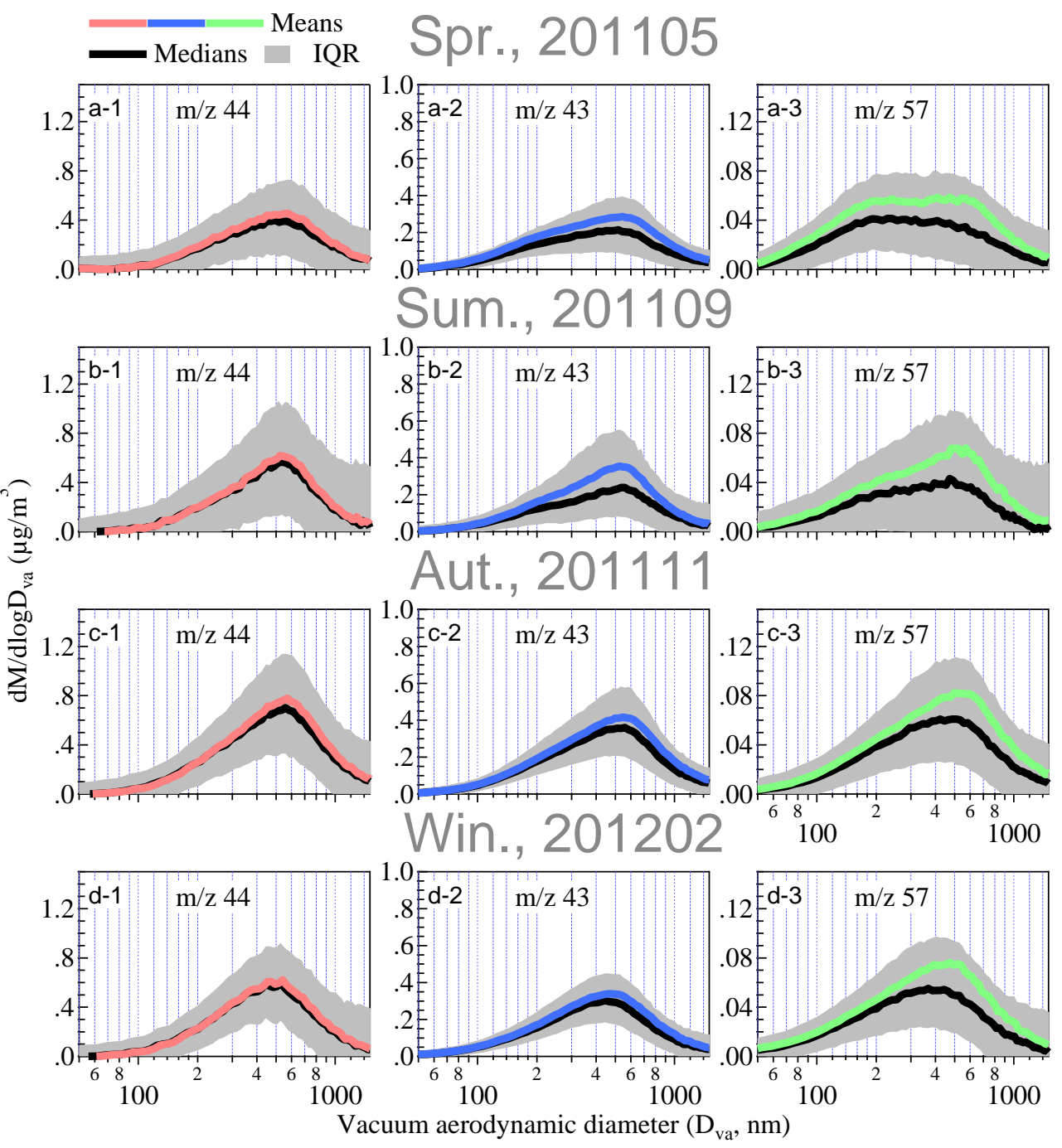

Figure 4. Size distributions of ions with $\mathrm{m} / \mathrm{z}$ values of 44,43 , and 57 in organics in the 4 months. The red, blue, and green lines are the means; the black lines are the medians; and the grey areas are the interquartile ranges (IQRs).

suburban sites have higher sulfate fractions. For the organic constituents, non-urban sites have much higher fractions of OOA than POA, which is in agreement with what has been reported worldwide (Zhang et al., 2011). This is true for Changdao (CDC), Heshan (HSC), Kaiping (KPC), and Hong Kong (HKC), but Jiaxing (JXC) and Shanghai (SHC) are exceptions. JXC is a suburban site and SHC is an urban site, but their POA and OOA distributions were quite similar. JXC was influenced strongly by biomass burning (BBOA) in the winter campaign (Huang et al., 2013), while only HOA contributed to POA in SHC (Huang et al., 2012). Overall, the fractions of species at our site are in line with those at other non-urban sites and the average SANO concentration is lower than those concentrations obtained from the nearby PRD area due to the strong influence of the oceanic air mass in some of the seasons.

\subsection{Size distributions}

Size distribution measurements of the HR-ToF-AMS provide additional information to identify the possible sources and processes leading to the PM species formation. The size distributions of sulfate, nitrate, and organics are displayed in Fig. 3. The secondary inorganic species, sulfate and nitrate, both had mass mode diameters $\left(D_{\mathrm{va}}\right)$ of 500 to $600 \mathrm{~nm}$. The smaller mode at $200 \mathrm{~nm}$ was more obvious for organics, especially in spring and summer (Fig. 3, a-3 and b-3), but the dominant mode for organics was still at $\sim 500 \mathrm{~nm}$. These size distributions suggest that PM at this site was generally affected by regional transport of aged particles. Local contribution was minor except for organics in spring and summer.

The size distributions of $m / z 44,43$, and 57 ions of organics are shown in Fig. 4. Signals with $m / z 43$ can be mainly attributed to $\mathrm{C}_{2} \mathrm{H}_{3} \mathrm{O}^{+}(>70 \%), m / z$, 44 to $\mathrm{CO}_{2}^{+}(>94 \%)$, and 


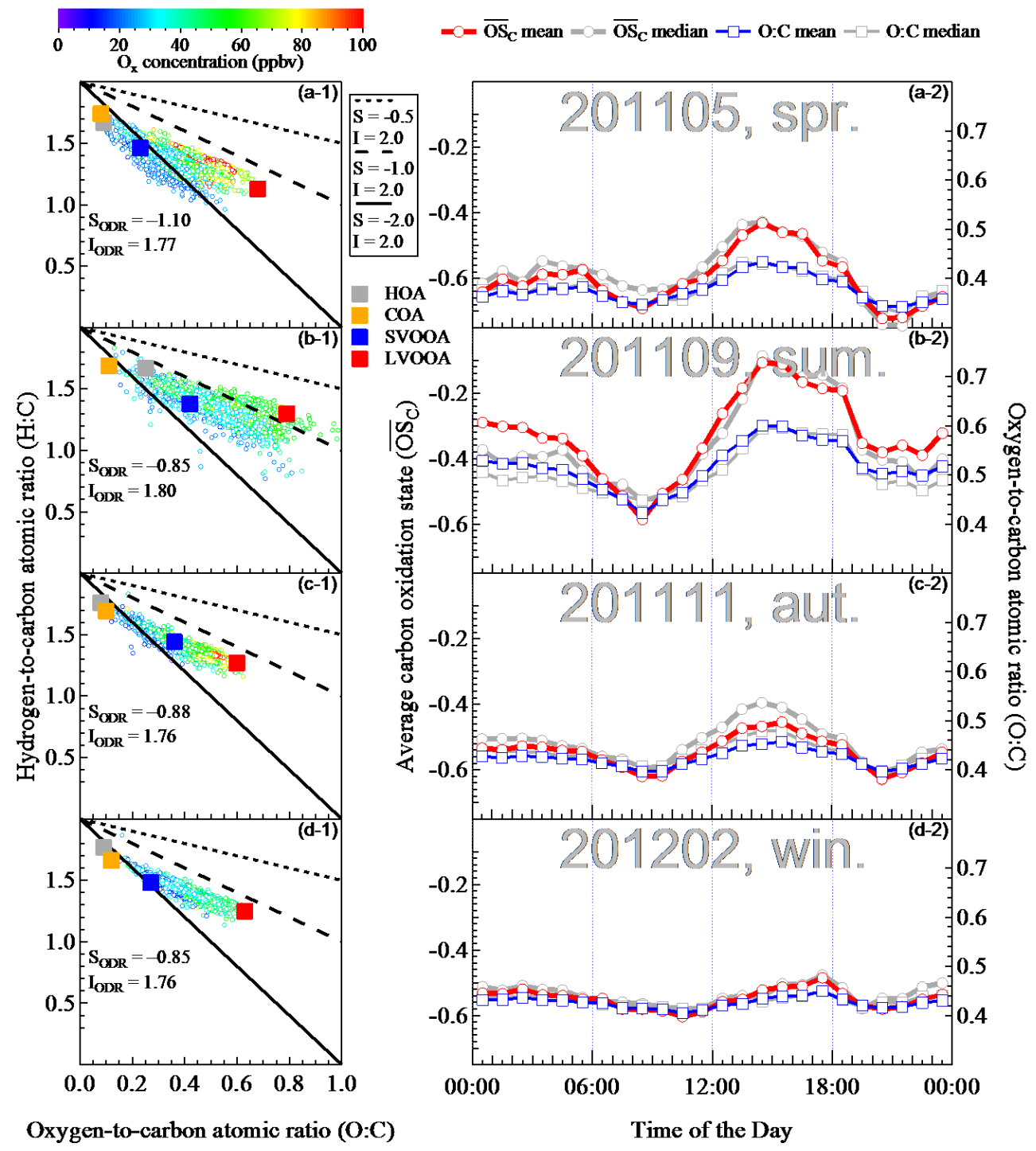

Figure 5. Summary of the degrees of oxygenation of organics in the 4 months. The left panels are the van Krevelen diagrams showing the $\mathrm{H}: \mathrm{C}$ vs $\mathrm{O}: \mathrm{C}$ ratios. Small open circles, representing the individual data points, were color-coded by $\mathrm{O}_{\mathrm{x}}$ concentration. Large solid squares are the average $\mathrm{H}: \mathrm{C}$ and $\mathrm{O}: \mathrm{C}$ ratios of the factors from PMF analysis. $\mathrm{S}_{\mathrm{ODR}}$ and $\mathrm{I}_{\mathrm{ODR}}$ are slopes and intercepts from orthogonal distance regression (ODR). Three lines with an intercept (I) of 2.0 and slopes (S) of $-0.5,-1.0$, and -2.0 are also added for reference. The right panels are the diurnal patterns of average carbon oxidation state $\left(\overline{\mathrm{OS}}_{\mathrm{C}}\right)$ and the $\mathrm{O}: \mathrm{C}$ ratio.

$m / z 57$ to $\mathrm{C}_{4} \mathrm{H}_{9}^{+}(>62 \%)$, and they only showed marginal seasonal dependence (1-11\% in their contributions). Ions with $m / z$ 44, which are contributed mainly by carboxylic acids ( $\mathrm{Ng}$ et al., 2010), had a size distribution similar to that of sulfate, with mass mode diameters peaking at 500 to $600 \mathrm{~nm}$. Carboxylic group formation in organics probably shared similar pathways with sulfate formation, such as gasphase oxidation or aqueous-phase processes. The $m / z 57$ ion had a clear peak at a smaller mode with $D_{\text {va }}$ of $\sim 200 \mathrm{~nm}$, especially in spring. It was mainly attributed to hydrocarbonlike organics that generate $\mathrm{C}_{4} \mathrm{H}_{9}^{+}$and its large fraction in a smaller mode at $\sim 200 \mathrm{~nm}$ indicates a large contribution of hydrocarbon-like organics from primary emissions such as traffic (Canagaratna et al., 2010; Sun et al., 2011). This small mode in the size distribution of $m / z 57$ was not as obvious in other seasons because of the lower contribution of air mass from the local urban area (see below). The $m / z 43$ ion has a degree of oxygenation between those of $m / z 44$ and $m / z 57$ and its size distribution exhibits the same trend. The size distributions of these ions of different degrees of oxygenation indicate the seasonal dependence of primary and secondary organics at this site. 


\subsection{Degree of oxygenation}

Figure 5 shows the results of elemental analysis in two ways. The panels on the left (a-1 through d-1) are the van Krevelen plots (Heald et al., 2010) for the 4 months, while the ones on the right (a-2 through d-2) are the diurnal patterns of average carbon oxidation state $\left(\overline{\mathrm{OS}}_{\mathrm{C}}\right)$ and oxygen-to-carbon atomic ratio $(\mathrm{O}: \mathrm{C})$. The spread of data points in the van Krevelen plot in spring (May 2011) has been discussed in detail by $\mathrm{Li}$ et al. (2013). Briefly, the spring campaign was separated into two foggy periods, one hazy period, and the "other" period. Because the chemical processes leading to SOA formation were different in the foggy and hazy periods, the data points clustered in different parts of the van Krevelen plot, resulting in different slopes and intercepts. Summer (September 2011) had the highest $\mathrm{O}: \mathrm{C}$ ratio among the four seasons, likely due to higher photochemical activity. This strong influence by photochemistry is also reflected by the higher average $\mathrm{O}: \mathrm{C}$ ratios in the PMF-resolved SVOOA and LVOOA factors (Fig. 5, left panels, large blue and red closed squares) in summer than in other seasons. In fact, the overall $\mathrm{O}: \mathrm{C}$ ratio was so high in summer that it might have had some effects on the PMF analysis, resulting in a high $\mathrm{CO}_{2}^{+}$fraction (0.1) and a high $\mathrm{O}: \mathrm{C}$ ratio $(0.25)$ in the HOA factor in summer. This abnormally high $\mathrm{O}: \mathrm{C}$ ratio $(>0.1)$ was also observed in other studies in remote or rural areas where highly oxygenated organics dominated the mass spectra (Saarikoski et al., 2012; $\mathrm{Hu}$ et al., 2013; Gilardoni et al., 2014). High $\mathrm{O}_{\mathrm{x}}$ concentration was associated with a high $\mathrm{O}: \mathrm{C}$ ratio because of the similar secondary nature of the two parameters. The data for autumn and winter (Fig. 5, c-1 and d-1, respectively) are more uniform than those for spring and summer and the slopes and intercepts of the van Krevelen plots are also quite similar. Since primary contributions to organic aerosol are generally small, these uniform elemental ratio correlations suggest similar processes (most likely during transport) and/or precursors in the oxidation of organics during autumn and winter. It is possible that the original characteristics of the freshly formed SOA were lost by the time they reached Hong Kong.

In all seasons, both representations of the degree of oxygenation $\left(\overline{\mathrm{OS}}_{\mathrm{C}}\right.$ and $\left.\mathrm{O}: \mathrm{C}\right)$ showed an afternoon peak in their diurnal patterns (right panels in Fig. 5). The peak is most prominent in summer (Fig. 5, b-2), further supporting that strong photochemistry leads to more oxidized organics. Since $\overrightarrow{\mathrm{OS}}_{\mathrm{C}}$ is estimated as $2 \times \mathrm{O}: \mathrm{C}-\mathrm{H}: \mathrm{C}$ (Kroll et al., 2011), $\mathrm{H}: \mathrm{C}$ can be reflected by the gaps between the red symbols $\left(\overline{\mathrm{OS}}_{\mathrm{C}}\right)$ and the blue symbols $(\mathrm{O}: \mathrm{C})$ in the right panels of Fig. 5. The largest gap was also observed in summer (Fig. 5, b-2), which was a result of low $\mathrm{H}: \mathrm{C}$ in the organics in this particular season (Fig. 5, b-1). Given that the organics were largely secondary, precursors of low $\mathrm{H}: \mathrm{C}$ in SOA formation such as aromatics or biogenic volatile organic compounds (BVOC) may have led to the observed low $\mathrm{H}: \mathrm{C}$ ratios. Although it is difficult to distinguish between these two types of precursors from the current data set, BVOC likely contributed substantially to SOA formation in summer because the site is surrounded by shrubby hills in three directions with relatively little traffic and industrial activities. The relatively high temperature in summer might facilitate more BVOC emission (Guenther et al., 1993), resulting in more SOA with a low $\mathrm{H}$ : $\mathrm{C}$ ratio. There are only small diurnal variations in the degree of oxygenation in both autumn and winter (Fig. 5, c-2 and d-2, respectively). The oxidized organics were likely transported to this site rather than locally formed.

\subsection{PMF factors}

PMF results were evaluated by time-series correlations of tracer species or ions and by mass-spectra correlations of similar factors (Table S3) from the literature (Zhang et al., 2011). We compared the trends of different species or proxies of species of potentially similar origins and characteristics. For example, as a transported species, LVOOA was compared with another transported species - sulfate. SVOOA was compared with nitrate since both are secondary and semi-volatile. $\mathrm{COA}$ was compared with three tracer ions $-\mathrm{C}_{5} \mathrm{H}_{8} \mathrm{O}^{+}, \mathrm{C}_{6} \mathrm{H}_{10} \mathrm{O}^{+}$, and $\mathrm{C}_{7} \mathrm{H}_{12} \mathrm{O}^{+}$(Sun et al., 2011). $\mathrm{HOA}$ was compared with $\mathrm{NO}_{\mathrm{x}}$ since both are traffic-related species. HR mass spectra of LVOOA $(n=4)$, SVOOA $(n=4)$, COA $(n=2)$, and HOA $(n=6)$ from a highresolution AMS spectral database (http://cires.colorado.edu/ jimenez-group/HRAMSsd/) were averaged and used for correlation analysis with PMF-resolved mass spectra from this study. From the inspection of tracer ions related to levoglucosan $\left(\mathrm{C}_{2} \mathrm{H}_{4} \mathrm{O}_{2}^{+}\right.$and $\mathrm{C}_{3} \mathrm{H}_{5} \mathrm{O}_{2}^{+}$) (Zhang et al., 2011) or lignin (Li et al., 2011), as well as the MS profiles of the PMF factors, biomass burning organic aerosol was not significant in the current study, although these characteristics might have been lost during aging processes (Hennigan et al., 2010; Li et al., 2014) before they were even transported to the site. COA showed a distinct diurnal pattern with peaks in the early evening, good correlations with the three tracer ions, and good correlations with mass spectra from the literature (panels 3-a through 3-d in Figs. S11, S13, S15, and S17). A COA factor was resolved from the single POA factor assigned earlier, namely the HOA factor (Lee et al., 2013; Li et al., 2013). This COA factor is also useful in choosing an initial number of factors. Based on the similarity between the time series or mass spectra of some of the factors and those of tracers and mass spectra in the literature, we believe that both LVOOA and SVOOA were split into two or three "sub-factors". Such splitting yields sub-factors that are not physically meaningful; thus they are combined to produce a single LVOOA or SVOOA factor. Table S3 summarizes the correlation analysis of time series and mass spectra before and after factor combination, with Pearson's $R\left(R_{\mathrm{Pr}}\right)$ for time series and uncentered $R\left(R_{\mathrm{UC}}\right)$ for mass spectra. The results of diagnostics and correlations are shown in Figs. S5 to S8 and an example of bootstrapping (May 2011, spring) is shown in Fig. S9. The 


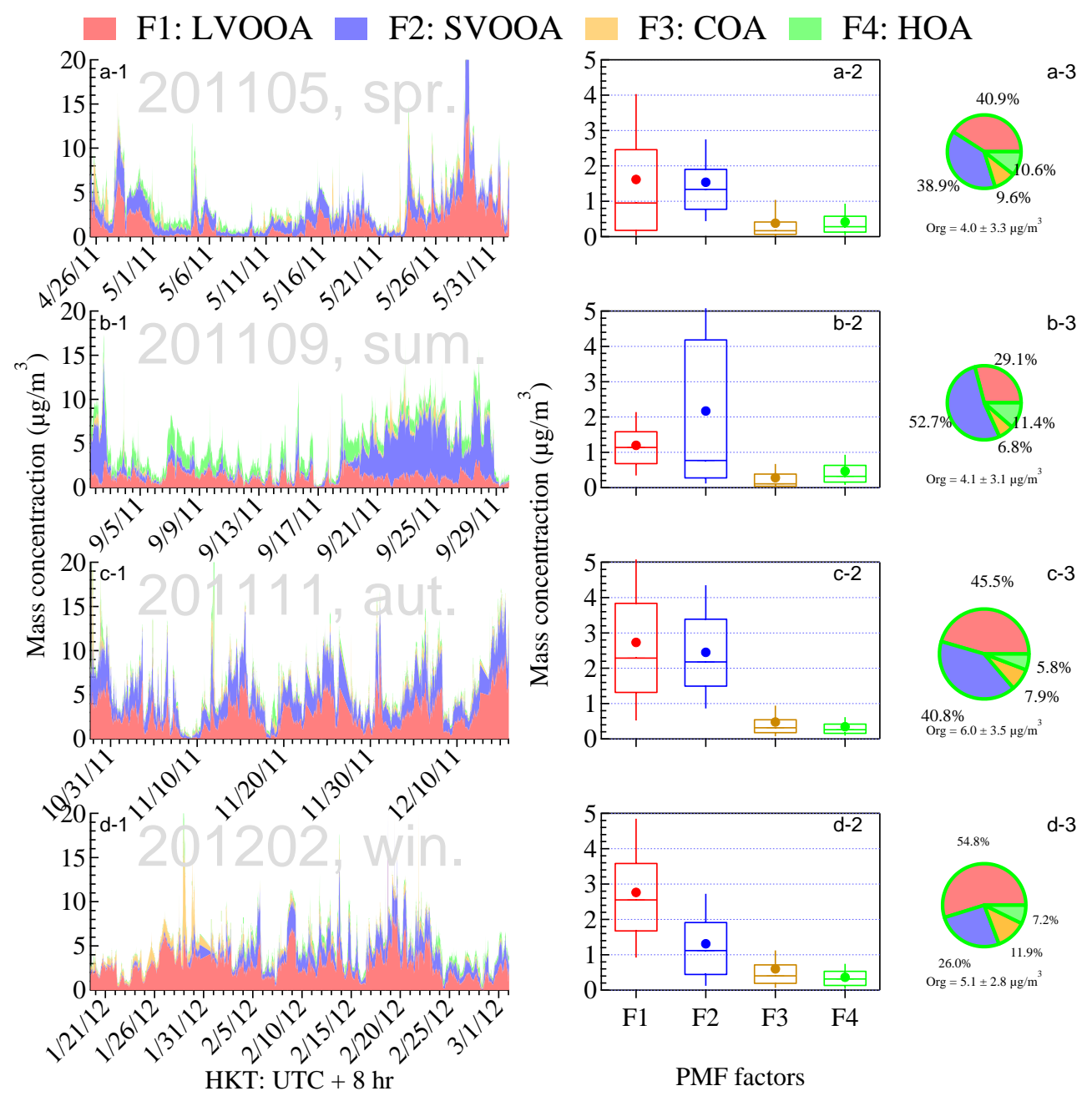

Figure 6. Summary of PMF-resolved organic factors (LVOOA, SVOOA, COA, and HOA) in NR-PM 1 in the 4 months. $\mathrm{x}-1$ : time series; $\mathrm{x}-2$ : monthly mean (dot), median (bar), 25 and $75 \%$ percentiles (box), and 10 and $90 \%$ percentiles (whiskers); x-3: monthly fraction (x-3), where "x" is "a" for spring (May 2011), "b" for summer (September 2011), "c" for autumn (November 2011), and "d" for winter (February 2012). Monthly averaged total organic concentrations are shown below the pie charts in $\mathrm{x}-3$ with 1 standard deviation. The area of a pie chart is proportional to the organic concentration.

combined four-factor solutions for all seasons are thus used for further analysis. Table S4 shows the elemental analysis results of the four factors in all seasons.

Shown in Fig. 6 are the time series (left panels), average concentrations (middle panels), and mass fractions (right panels) of each PMF-resolved factor in the organics in the combined four-factor solutions in each season. Assuming LVOOA and SVOOA can act as surrogates of "aged" and "fresh" SOA, respectively (Jimenez et al., 2009), over $80 \%$ of the organics in NR-PM $\mathrm{P}_{1}$ were of secondary nature in all four seasons. The relative contributions of LVOOA and SVOOA showed clear seasonal dependence. Summer (Fig. 6, b-3) had the highest SVOOA fraction of up to $53 \%$. Winter (Fig. 6, d-3) had the highest LVOOA fraction of up to $55 \%$, in accordance with our previous discussion that the site was under the influence of long-range transport in this particular season. The COA fractions in both spring and winter were higher than those in the other two seasons, probably due to low wind speed (Table 2), which limited dispersion. The fractions of HOA in spring and summer were higher than those in the other months, which can be attributed to the air mass origin to be discussed in the next section. Note that the two POA factors $\mathrm{COA}$ and HOA behaved slightly differently because COA was mainly contributed by a student canteen nearby and stagnant air will facilitate the accumulation of this primary emission, while HOA was mainly from the urban area and its contribution was higher when the wind direction was from the south. 

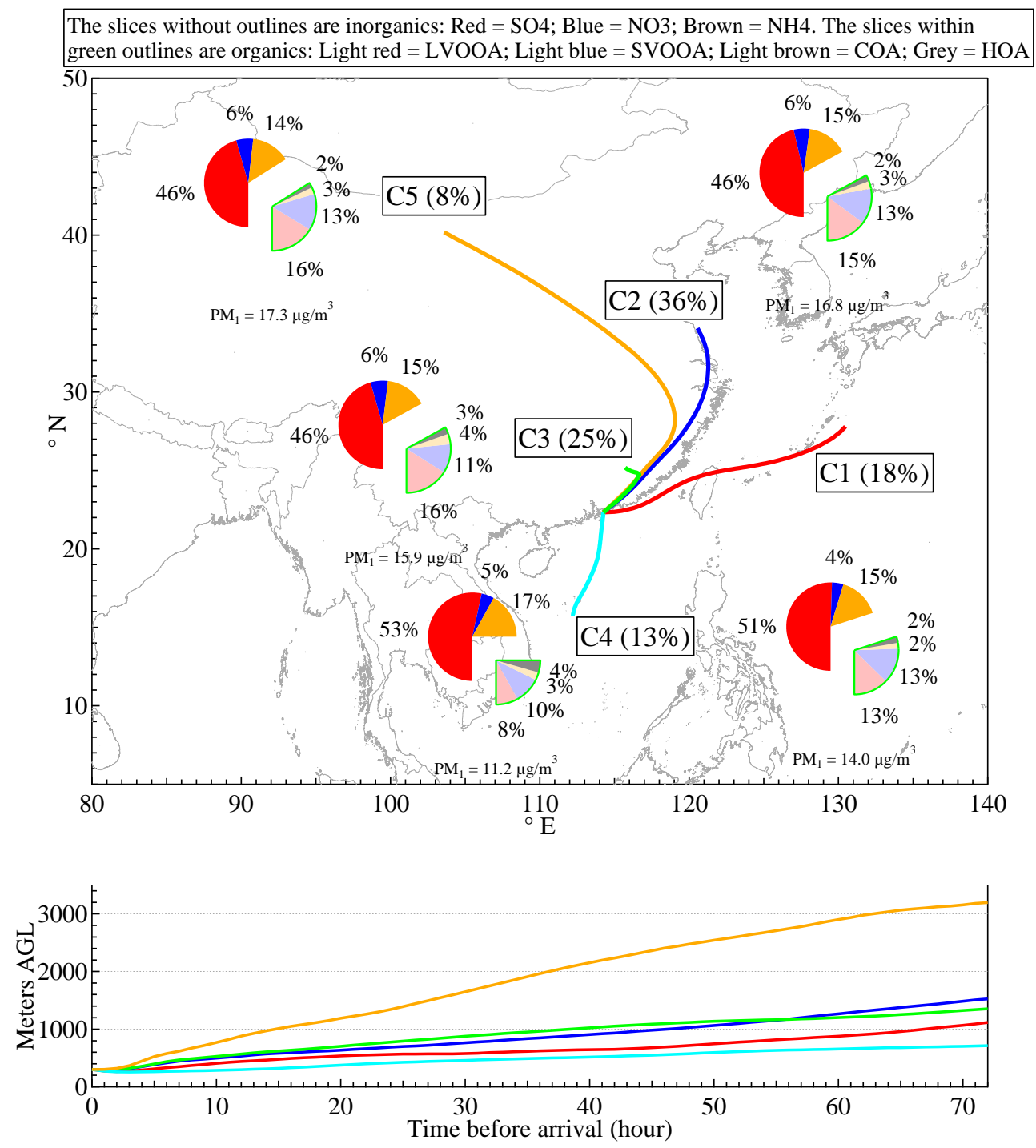

Figure 7. Average fractions of sulfate, ammonium, nitrate, and organics with PMF-resolved LVOOA, SVOOA, COA, and HOA in different clusters from the five-cluster solution at $300 \mathrm{~m}$ arrival height (AGL: above ground level). The colored lines in the upper panel show the average trajectories, and the corresponding colored lines in the lower panel show the vertical profiles of those trajectories.

\subsection{Back-trajectory analysis}

Although the average NR-PM $\mathrm{PM}_{1}$ concentration had little dependence on the season, it had a strong dependence on the air mass origin, as shown in Fig. 7. Continental air masses (clusters 2, 3, and 5) showed average NR-PM 1 concentrations of $16-17 \mu \mathrm{g} \mathrm{m}^{-3}$. The air masses from the South China Sea (cluster 4) showed the lowest NR-PM 1 concentration $\left(11.2 \mu \mathrm{g} \mathrm{m}^{-3}\right)$. The air masses from the East China Sea (cluster 1) showed NR-PM 1 concentration of $14.0 \mu \mathrm{g} \mathrm{m}^{-3}$.

The three clusters with continental air mass origins (clusters 2, 3, and 5) had similar mass concentrations as well as fractions of species. For example, sulfate and nitrate fractions in all three clusters were 46 and $6 \%$, respectively. Ammonium fractions were $14-15 \%$ and LVOOA fractions were
15-16\%. Cluster 3 had slightly higher POA (HOA and COA) fractions than the other two continental clusters, but a lower SVOOA fraction (10\% in cluster 3 compared with $13 \%$ in the other two). Cluster 3, with a short mean trajectory, mainly consists of circulating trajectories within the PRD region due to the effect of land-sea breeze in relatively weak background winds. This relatively calm meteorological condition may favor the accumulation of locally emitted air pollutants. In clusters 1 and 4 , over $50 \%$ of NR-PM 1 mass was sulfate, suggesting that a marine air mass can still transport significant amounts of sulfate to the site, presumably due to oxidation of dimethyl sulfide (Warneck, 2000) or residual sulfate accumulating in the ocean after long-range transport. The fraction of HOA in cluster 4 was the highest among all clusters. The site was downwind of the highly urbanized down- 


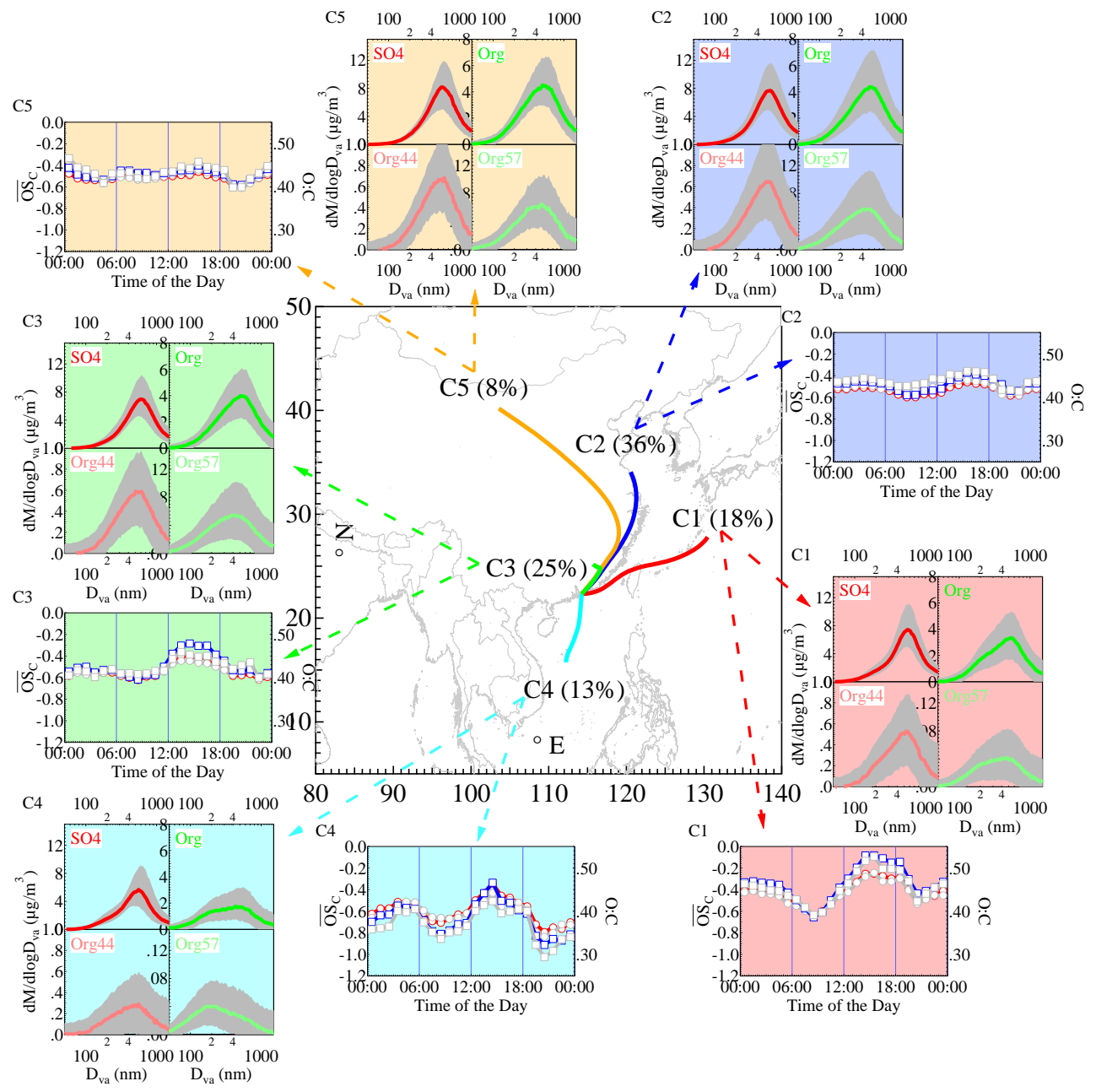

Figure 8. Average size distributions of sulfate (SO4), organics (Org), organics with $m / z 44$ (Org44) and organics with $m / z$ 57 (Org57), and diurnal patterns of the degree of oxygenation of organics, as represented by average carbon oxidation state $\left(\overline{\mathrm{OS}}_{\mathrm{C}}\right)$ and $\mathrm{O}$ : $\mathrm{C}$ ratio in different clusters from the five-cluster solution at $300 \mathrm{~m}$ arrival height. For size distributions, the colored lines indicate the average size distributions, while the grey areas indicate the IQRs. For diurnal patterns of $\overline{\mathrm{OS}}_{\mathrm{C}}$ and $\mathrm{O}: \mathrm{C}$, legends are the same as those in Fig. 5 (on top of right panels).

town area. It was more affected by traffic-related emissions in cluster 4 than in other clusters. As shown in Table 1, 35 and $17 \%$ of the time in spring and summer, respectively, was associated with cluster 4 . The monthly averaged high HOA fractions in these two seasons (see Fig. 6, panels a-3 and b-3) were thus clearly affected by the air mass origins represented by cluster 4 .

Figure 8 shows the size distributions of sulfate, organics, and organics with $m / z$ values of 44 (Org44) and 57 (Org57) in all five clusters. As discussed above, the peak at $\sim 200 \mathrm{~nm}$ in organics and Org57 may be due to primary emissions of vehicular exhausts (Canagaratna et al., 2010; Sun et al., 2011). This peak is clearly observed in cluster 4 , which reinforces our conclusion that traffic-related emissions from the downtown area in the southwest had a strong influence on

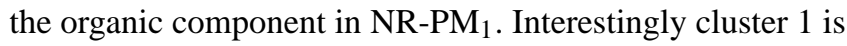
probably also affected by traffic emissions, albeit to a smaller extent, since the same shoulder peak is also observed. Sulfate and Org44 both peak at a larger size of around 500 to $600 \mathrm{~nm}$. A small shoulder peak at around $200 \mathrm{~nm}$ for Org44 is observed in clusters 1, 3, and 4, suggesting fresher locally produced oxidized organics are important during the periods of these clusters.

From the diurnal patterns of the degree of oxygenation $\left(\overline{\mathrm{OS}}_{\mathrm{C}}\right.$ and $\left.\mathrm{O}: \mathrm{C}\right)$ also shown in Fig. 8, clusters 1, 3, and 4 had the most obvious diurnal variations, suggesting that more local oxidation of organics may have occurred under the strong photochemical activity near the site. In clusters 1 and 4 , the degree of oxygenation of organics showed sharp decreases in the morning after 06:00 LT and milder decreases in the evening after 18:00 LT. This observation corresponds to higher emissions of traffic-related HOA, whose degree of oxygenation is low, in these two clusters and is in good agreement with previous analysis showing that the site was 
strongly affected by local traffic emissions in clusters 1 and 4. Conversion of HOA to SOA during the day resulted in increases in the degree of oxygenation of organics in the two clusters. Without such obvious decreases in rush hours in cluster 3 , the increase in degree of oxygenation at noon in this cluster is significant, with a mean $\mathrm{O}: \mathrm{C}$ increase of $\sim 0.1$ from 08:00 to 14:00 LT. The calm winds in cluster 3 can thus facilitate local SOA formation during daytime. Together with the earlier size distribution data analysis, we believe that, during the periods of these three clusters, locally formed oxidized organics were more prevalent than transported ones. In contrast, the diurnal variations in the degree of oxygenation in clusters 2 and 5 are not obvious, suggesting oxidized organics were mostly transported to the site.

\section{Conclusions and atmospheric implications}

We investigated NR-PM ${ }_{1}$ composition with highly timeresolved HR-ToF-AMS measurements in four seasons at the HKUST Supersite. Several major conclusions may be drawn.

1. NR-PM $M_{1}$ at the HKUST Supersite was highly aged, with a high sulfate content and highly oxygenated organic components. Monthly average sulfate mass fraction ranged from 40 to $56 \%$ and the peak $\mathrm{O}: \mathrm{C}$ ratio in the diurnal pattern of summer was up to 0.6 .

2. Seasonal variation in NR-PM $\mathrm{PM}_{1}$ concentration was not obvious ( 14.3 to $15.9 \mu \mathrm{g} \mathrm{m}^{-3}$ ) but the relative fractions of different species showed strong seasonal dependence. In terms of percentages of species in the NR-PM 1 mass, sulfate was highest in summer $(56 \%)$ and lowest in winter $(40 \%)$. Nitrate was highest in winter $(10 \%)$ with the low temperatures. Organics were high in autumn (38\%) and winter $(33 \%)$, with the air originating mainly from the continent.

3. Both NR-PM $M_{1}$ concentrations and the relative fractions showed a strong dependence on air mass origin. Averaged NR-PM $M_{1}$ concentration ranged from 11.2 to $17.3 \mu \mathrm{g} \mathrm{m}^{-3}$, depending on air mass origin. The diurnal pattern of the degree of oxygenation was more pronounced in the periods when the air masses originated from the ocean, while it varied little in the periods when the air masses originated from the continent with longrange transport.

4. Both locally produced and regionally transported organic aerosols contribute to the organic content of $\mathrm{PM}$ at this site, and the degree of contribution depends strongly on the season as well as the air mass origin.

The last point is of particular interest when trying to identify the source of organics in PM pollution. Traffic-related HOA had a relatively higher fraction in organic aerosols in spring and summer, when air masses came mainly from the ocean, and they brought local traffic emissions from downtown areas to the site. COA had the highest fraction when the air masses were circulating within the PRD region (cluster 3). The degree of oxygenation showed the most obvious diurnal patterns in summer and spring and in clusters of less continental influence (clusters 1,3 , and 4), reflecting the importance of locally produced SOA. Clusters 2 and 5, which are associated mainly with winter and autumn, had little variation in diurnal patterns of degree of oxygenation of organics. This suggests that organic aerosols, most likely dominated by SOA, were transported to the site in autumn and winter.

The AMS NR-PM 1 compositions at this suburban site are similar to those reported in the literature for other non-urban sites in Asia in terms of the fractions of NR-PM $\mathrm{PM}_{1}$ species. However, the NR-PM 1 concentration is lower than those reported for the nearby PRD area, probably due to the strong influence of the oceanic air mass in some seasons and the low level of locally emitted anthropogenic particles near this suburban site. Sulfate fraction (four-season average $48 \%$ ) in the current study is even higher than those at remote sites such as Jiju, Korea (JJK, 36\%), and Fukue, Japan (FKJ, $40 \%$ ). The four-season average mass concentration of sulfate of $7.3 \mu \mathrm{g} \mathrm{m}^{-3}$ at the suburban site in Hong Kong is close to those concentrations measured at four other sites in the PRD region $\left(\sim 10 \mu \mathrm{g} \mathrm{m}^{-3}\right)$, but much higher than those measured in JJK and FKJ ( 3 to $4 \mu \mathrm{g} \mathrm{m}^{-3}$ ). Hence, sulfate in the PRD might have a much higher "background" concentration (7 to $10 \mu \mathrm{g} \mathrm{m}^{-3}$ ) than in East Asia. The quality of fossil fuel (especially coal) should be better controlled and the usage of desulfurization technology (Zhao et al., 2010) should be better implemented.

In this study, there was a large seasonal effect on the NR$\mathrm{PM}_{1}$ species distribution and the chemical characteristics of organic aerosols, but a much weaker one on the overall NR$\mathrm{PM}_{1}$ concentration. On the other hand, both NR-PM 1 concentration and chemical characteristics are sensitive to air mass origin. SOA, as indicated by the PMF-resolved OOA factors, had much higher mass fractions (5 times) than did POA (mainly COA and HOA) at this suburban site. This is also reflected by the high degree of oxygenation of the organic components. Therefore, this site is strongly influenced by secondary formation of organic aerosols. The HKUST Supersite is thus a suitable location for gaining a better understanding of the processes leading to SOA formation in the region.

The Supplement related to this article is available online at doi:10.5194/acp-15-37-2015-supplement. 
Acknowledgements. This work was supported by the Environmental Conservation Fund of Hong Kong (project number ECWW09EG04) and the Research Grants Council of the Hong Kong Special Administrative Region, China (General Research Fund 600413).

Edited by: B. Ervens

\section{References}

Aiken, A. C., DeCarlo, P. F., and Jimenez, J. L.: Elemental analysis of organic species with electron ionization high-resolution mass spectrometry, Anal. Chem., 79, 8350-8358, 2007.

Aiken, A. C., Decarlo, P. F., Kroll, J. H., Worsnop, D. R., Huffman, J. A., Docherty, K. S., Ulbrich, I. M., Mohr, C., Kimmel, J. R., Sueper, D., Sun, Y., Zhang, Q., Trimborn, A., Northway, M., Ziemann, P. J., Canagaratna, M. R., Onasch, T. B., Alfarra, M. R., Prevot, A. S. H., Dommen, J., Duplissy, J., Metzger, A., Baltensperger, U., and Jimenez, J. L.: O / C and OM / OC ratios of primary, secondary, and ambient organic aerosols with high-resolution time-of-flight aerosol mass spectrometry, Environ. Sci. Technol., 42, 4478-4485, 2008.

Aiken, A. C., Salcedo, D., Cubison, M. J., Huffman, J. A., DeCarlo, P. F., Ulbrich, I. M., Docherty, K. S., Sueper, D., Kimmel, J. R., Worsnop, D. R., Trimborn, A., Northway, M., Stone, E. A., Schauer, J. J., Volkamer, R. M., Fortner, E., de Foy, B., Wang, J., Laskin, A., Shutthanandan, V., Zheng, J., Zhang, R., Gaffney, J., Marley, N. A., Paredes-Miranda, G., Arnott, W. P., Molina, L. T., Sosa, G., and Jimenez, J. L.: Mexico City aerosol analysis during MILAGRO using high resolution aerosol mass spectrometry at the urban supersite (T0) - Part 1: Fine particle composition and organic source apportionment, Atmos. Chem. Phys., 9, 6633-6653, doi:10.5194/acp-9-6633-2009, 2009.

Allan, J. D., Alfarra, M. R., Bower, K. N., Williams, P. I., Gallagher, M. W., Jimenez, J. L., McDonald, A. G., Nemitz, E., Canagaratna, M. R., Jayne, J. T., Coe, H., and Worsnop, D. R.: Quantitative sampling using an Aerodyne aerosol mass spectrometer - 2. Measurements of fine particulate chemical composition in two U.K. cities, J. Geophys. Res.-Atmos., 108, 4091, doi:4010.1029/2002jd002359, 2003.

Allan, J. D., Delia, A. E., Coe, H., Bower, K. N., Alfarra, M. R., Jimenez, J. L., Middlebrook, A. M., Drewnick, F., Onasch, T. B., Canagaratna, M. R., Jayne, J. T., and Worsnop, D. R.: A generalised method for the extraction of chemically resolved mass spectra from aerodyne aerosol mass spectrometer data, J. Aerosol Sci., 35, 909-922, 2004.

Canagaratna, M. R., Onasch, T. B., Wood, E. C., Herndon, S. C., Jayne, J. T., Cross, E. S., Miake-Lye, R. C., Kolb, C. E., and Worsnop, D. R.: Evolution of Vehicle Exhaust Particles in the Atmosphere, J. Air Waste Manage. Assoc., 60, 1192-1203, 2010.

Chan, C. K. and Yao, X.: Air pollution in mega cities in China, Atmos. Environ., 42, 1-42, 2008.

DeCarlo, P. F., Kimmel, J. R., Trimborn, A., Northway, M. J., Jayne, J. T., Aiken, A. C., Gonin, M., Fuhrer, K., Horvath, T., Docherty, K. S., Worsnop, D. R., and Jimenez, J. L.: Field-deployable, high-resolution, time-of-flight aerosol mass spectrometer, Anal. Chem., 78, 8281-8289, 2006.
Draxler, R. R. and Hess, G. D.: Description of the HYSPLIT_4 modeling system, available at: http://www.arl.noaa.gov/ documents/reports/arl-224.pdf (last access: 5 January 2014), NOAA Air Resources Laboratory, Silver Spring, Maryland, USA, 1997.

Draxler, R. R., Stunder, B., Rolph, G., Stein, A., and Taylor, A.: HYSPLIT_4 User's Guide, available at http://www.arl.noaa.gov/ documents/reports/hysplit_user_guide.pdf (last access: 5 January 2014), NOAA Air Resources Laboratory, Silver Spring, Maryland, USA, 2012a.

Draxler, R. R., Stunder, B., Rolph, G., Stein, A., and Taylor, A.: HYSPLIT tutorial, available at: http://www.arl.noaa.gov/ documents/workshop/Spring2011/HYSPLIT_Tutorial.pdf (last access: 5 January 2014), NOAA Air Resources Laboratory, Silver Spring, Maryland, USA, 2012b.

Gilardoni, S., Massoli, P., Giulianelli, L., Rinaldi, M., Paglione, M., Pollini, F., Lanconelli, C., Poluzzi, V., Carbone, S., Hillamo, R., Russell, L. M., Facchini, M. C., and Fuzzi, S.: Fog scavenging of organic and inorganic aerosol in the Po Valley, Atmos. Chem. Phys., 14, 6967-6981, doi:10.5194/acp-14-6967-2014, 2014.

Gong, Z. H., Lan, Z. J., Xue, L., Zeng, L. W., He, L. Y., and Huang, X. F.: Characterization of submicron aerosols in the urban outflow of the central Pearl River Delta region of China, Front. Env. Sci. Eng., 6, 725-733, 2012.

Guenther, A. B., Zimmerman, P. R., Harley, P. C., Monson, R. K., and Fall, R.: Isoprene and Monoterpene Emission Rate Variability - Model Evaluations and Sensitivity Analyses, J. Geophys. Res.-Atmos., 98, doi:10.1029/93jd00527, 12609-12617, 1993.

He, L. Y., Huang, X. F., Xue, L., Hu, M., Lin, Y., Zheng, J., Zhang, R. Y., and Zhang, Y. H.: Submicron aerosol analysis and organic source apportionment in an urban atmosphere in Pearl River Delta of China using high-resolution aerosol mass spectrometry, J. Geophys. Res.-Atmos., 116, D12304, doi:10.1029/2010JD014566, 2011.

Heald, C. L., Kroll, J. H., Jimenez, J. L., Docherty, K. S., DeCarlo, P. F., Aiken, A. C., Chen, Q., Martin, S. T., Farmer, D. K., and Artaxo, P.: A simplified description of the evolution of organic aerosol composition in the atmosphere, Geophys. Res. Lett., 37, L08803, doi:10.1029/2010g1042737, 2010.

Hennigan, C. J., Sullivan, A. P., Collett, J. L., Jr., and Robinson, A. L.: Levoglucosan stability in biomass burning particles exposed to hydroxyl radicals, Geophys. Res. Lett., 37, L09806, doi:10.1029/2010g1043088, 2010.

Hu, D. and Yu, J. Z.: Secondary organic aerosol tracers and malic acid in Hong Kong: seasonal trends and origins, Environ. Chem., 10, 381-394, 2013.

Hu, W. W., Hu, M., Yuan, B., Jimenez, J. L., Tang, Q., Peng, J. F., Hu, W., Shao, M., Wang, M., Zeng, L. M., Wu, Y. S., Gong, Z. H., Huang, X. F., and He, L. Y.: Insights on organic aerosol aging and the influence of coal combustion at a regional receptor site of central eastern China, Atmos. Chem. Phys., 13, 10095-10112, 2013, http://www.atmos-chem-phys.net/13/10095/2013/.

Huang, X. F., Yu, J. Z., Yuan, Z. B., Lau, A. K. H., and Louie, P. K. K.: Source analysis of high particulate matter days in Hong Kong, Atmos. Environ., 43, 1196-1203, 2009.

Huang, X.-F., He, L.-Y., Hu, M., Canagaratna, M. R., Kroll, J. H., Ng, N. L., Zhang, Y.-H., Lin, Y., Xue, L., Sun, T.-L., Liu, X.-G., Shao, M., Jayne, J. T., and Worsnop, D. R.: Characterization of 
submicron aerosols at a rural site in Pearl River Delta of China using an Aerodyne High-Resolution Aerosol Mass Spectrometer, Atmos. Chem. Phys., 11, 1865-1877, doi:10.5194/acp-11-18652011, 2011.

Huang, X.-F., He, L.-Y., Xue, L., Sun, T.-L., Zeng, L.-W., Gong, Z.-H., Hu, M., and Zhu, T.: Highly time-resolved chemical characterization of atmospheric fine particles during 2010 Shanghai World Expo, Atmos. Chem. Phys., 12, 4897-4907, doi:10.5194/acp-12-4897-2012, 2012.

Huang, X. F., Xue, L., Tian, X. D., Shao, W. W., Sun, T. L., Gong, Z. H., Ju, W. W., Jiang, B., Hu, M., and He, L. Y.: Highly timeresolved carbonaceous aerosol characterization in Yangtze River Delta of China: Composition, mixing state and secondary formation, Atmos. Environ., 64, 200-207, 2013.

Jimenez, J. L., Canagaratna, M. R., Donahue, N. M., Prevot, A. S. H., Zhang, Q., Kroll, J. H., DeCarlo, P. F., Allan, J. D., Coe, H., Ng, N. L., Aiken, A. C., Docherty, K. S., Ulbrich, I. M., Grieshop, A. P., Robinson, A. L., Duplissy, J., Smith, J. D., Wilson, K. R., Lanz, V. A., Hueglin, C., Sun, Y. L., Tian, J., Laaksonen, A., Raatikainen, T., Rautiainen, J., Vaattovaara, P., Ehn, M., Kulmala, M., Tomlinson, J. M., Collins, D. R., Cubison, M. J., Dunlea, E. J., Huffman, J. A., Onasch, T. B., Alfarra, M. R., Williams, P. I., Bower, K., Kondo, Y., Schneider, J., Drewnick, F., Borrmann, S., Weimer, S., Demerjian, K., Salcedo, D., Cottrell, L., Griffin, R., Takami, A., Miyoshi, T., Hatakeyama, S., Shimono, A., Sun, J. Y., Zhang, Y. M., Dzepina, K., Kimmel, J. R., Sueper, D., Jayne, J. T., Herndon, S. C., Trimborn, A. M., Williams, L. R., Wood, E. C., Middlebrook, A. M., Kolb, C. E., Baltensperger, U., and Worsnop, D. R.: Evolution of organic aerosols in the atmosphere, Science, 326, 1525-1529, 2009.

Kroll, J. H., Donahue, N. M., Jimenez, J. L., Kessler, S. H., Canagaratna, M. R., Wilson, K. R., Altieri, K. E., Mazzoleni, L. R., Wozniak, A. S., Bluhm, H., Mysak, E. R., Smith, J. D., Kolb, C. E., and Worsnop, D. R.: Carbon oxidation state as a metric for describing the chemistry of atmospheric organic aerosol, Nature Chem., 3, 133-139, 2011.

Lanz, V. A., Alfarra, M. R., Baltensperger, U., Buchmann, B., Hueglin, C., and Prévôt, A. S. H.: Source apportionment of submicron organic aerosols at an urban site by factor analytical modelling of aerosol mass spectra, Atmos. Chem. Phys., 7, 15031522, doi:10.5194/acp-7-1503-2007, 2007.

Lau, J., Hung, W. T., Cheung, C. S., and Yuen, D.: Contributions of roadside vehicle emissions to general air quality in Hong Kong, Transport Res D-Tr E, 13, 19-26, 2008.

Lee, B. Y. L., Li, Y. J., Yu, J. Z., Louie, K. K. P., and Chan, C. K.: Characteristics of ambient aerosol at a suburban site in Hong Kong during springtime, J. Geophys. Res.-Atmos., 118, doi:10.1002/jgrd.50658, 8625-8639, 2013.

Li, Y. J., Yeung, J. W. T., Leung, T. P. I., Lau, A. P. S., and Chan, C. K.: Characterization of Organic Particles from Incense Burning Using an Aerodyne High-Resolution Time-of-Flight Aerosol Mass Spectrometer, Aerosol Sci. Technol., 46, 654-665, 2011.

Li, Y., Lau, A. K. H., Fung, J. C. H., Zheng, J. Y., Zhong, L. J., and Louie, P. K. K.: Ozone source apportionment (OSAT) to differentiate local regional and super-regional source contributions in the Pearl River Delta region, China, J. Geophys. Res.-Atmos., 117, D15305, doi:10.1029/2011jd017340, 2012.

Li, Y. J., Lee, B. Y. L., Yu, J. Z., Ng, N. L., and Chan, C. K.: Evaluating the degree of oxygenation of organic aerosol during foggy and hazy days in Hong Kong using high-resolution time-offlight aerosol mass spectrometry (HR-ToF-AMS), Atmos. Chem. Phys., 13, 8739-8753, doi:10.5194/acp-13-8739-2013, 2013.

Li, Y. J., Huang, D. D., Cheung, H. Y., Lee, A. K. Y., and Chan, C. K.: Aqueous-phase photochemical oxidation and direct photolysis of vanillin - a model compound of methoxy phenols from biomass burning, Atmos. Chem. Phys., 14, 2871-2885, doi:10.5194/acp-14-2871-2014, 2014.

Louie, P. K. K., Watson, J. G., Chow, J. C., Chen, A., Sin, D. W. M., and Lau, A. K. H.: Seasonal characteristics and regional transport of $\mathrm{PM}_{2.5}$ in Hong Kong, Atmos. Environ., 39, 1695-1710, 2005.

Meng, J. W., Yeung, M. C., Li, Y. J., Lee, B. Y. L., and Chan, C. K.: Size-resolved cloud condensation nuclei (CCN) activity and closure analysis at the HKUST Supersite in Hong Kong, Atmos. Chem. Phys., 14, 10267-10282, doi:10.5194/acp-1410267-2014, 2014.

Middlebrook, A. M., Bahreini, R., Jimenez, J. L., and Canagaratna, M. R.: Evaluation of Composition-Dependent Collection Efficiencies for the Aerodyne Aerosol Mass Spectrometer using Field Data, Aerosol Sci. Technol., 46, 258-271, 2012.

Ng, N. L., Canagaratna, M. R., Zhang, Q., Jimenez, J. L., Tian, J., Ulbrich, I. M., Kroll, J. H., Docherty, K. S., Chhabra, P. S., Bahreini, R., Murphy, S. M., Seinfeld, J. H., Hildebrandt, L., Donahue, N. M., DeCarlo, P. F., Lanz, V. A., Prévôt, A. S. H., Dinar, E., Rudich, Y., and Worsnop, D. R.: Organic aerosol components observed in Northern Hemispheric datasets from Aerosol Mass Spectrometry, Atmos. Chem. Phys., 10, 46254641, doi:10.5194/acp-10-4625-2010, 2010.

Paatero, P. and Tapper, U.: Positive Matrix Factorization - a Nonnegative Factor Model with Optimal Utilization of ErrorEstimates of Data Values, Environmetrics, 5, 111-126, 1994.

Saarikoski, S., Carbone, S., Decesari, S., Giulianelli, L., Angelini, F., Canagaratna, M., Ng, N. L., Trimborn, A., Facchini, M. C., Fuzzi, S., Hillamo, R., and Worsnop, D.: Chemical characterization of springtime submicrometer aerosol in Po Valley, Italy, Atmos. Chem. Phys., 12, 8401-8421, doi:10.5194/acp-12-84012012, 2012.

Seinfeld, J. H. and Pandis, S. N.: Atmospheric chemistry and physics: From air pollution to climate change, 2nd ed., Wiley, New Jersey, 474 pp., 2006.

Sueper, D.: ToF-AMS data analysis software, available at: http://cires.colorado.edu/jimenez-group/ToFAMSResources/ ToFSoftware/index.html, last access: 1 December 2013.

Sun, Y.-L., Zhang, Q., Schwab, J. J., Demerjian, K. L., Chen, W.N., Bae, M.-S., Hung, H.-M., Hogrefe, O., Frank, B., Rattigan, O. V., and Lin, Y.-C.: Characterization of the sources and processes of organic and inorganic aerosols in New York city with a high-resolution time-of-flight aerosol mass apectrometer, Atmos. Chem. Phys., 11, 1581-1602, doi:10.5194/acp-11-15812011, 2011.

Sun, Y. L., Wang, Z. F., Fu, P. Q., Yang, T., Jiang, Q., Dong, H. B., Li, J., and Jia, J. J.: Aerosol composition, sources and processes during wintertime in Beijing, China, Atmos. Chem. Phys., 13, 4577-4592, doi:10.5194/acp-13-4577-2013, 2013.

Ulbrich, I. M., Canagaratna, M. R., Zhang, Q., Worsnop, D. R., and Jimenez, J. L.: Interpretation of organic components from Positive Matrix Factorization of aerosol mass spectrometric data, Atmos. Chem. Phys., 9, 2891-2918, doi:10.5194/acp-9-2891-2009, 2009. 
Wang, W., Bruyere, M., Duda, M., Dudhia, J., Gill, D., Kavulich, M., Keene, K., Lin, H., Michalakes, J., Rizvi, S., and Zhang, X.: Weather Research and Forecasting ARW version 3 modeling system user's guide, available at: http://www2.mmm.ucar.edu/wrf/ users/docs/user_guide_V3/ARWUsersGuideV3.pdf (last access: July 2014), Mesoscale and Microscale Meteorology Division, National Center for Atmospheric Research, Boulder, CO, USA, 2014.

Warneck, P.: Chemistry of the natural atmosphere, 2nd ed., Academic Press, San Diego, CA, 589 pp., 2000.

Wu, D., Wu, C., Liao, B., Chen, H., Wu, M., Li, F., Tan, H., Deng, T., Li, H., Jiang, D., and Yu, J. Z.: Black carbon over the South China Sea and in various continental locations in South China, Atmos. Chem. Phys., 13, 12257-12270, doi:10.5194/acp13-12257-2013, 2013.

Xiao, R., Takegawa, N., Zheng, M., Kondo, Y., Miyazaki, Y., Miyakawa, T., Hu, M., Shao, M., Zeng, L., Gong, Y., Lu, K., Deng, Z., Zhao, Y., and Zhang, Y. H.: Characterization and source apportionment of submicron aerosol with aerosol mass spectrometer during the PRIDE-PRD 2006 campaign, Atmos. Chem. Phys., 11, 6911-6929, doi:10.5194/acp-11-6911-2011, 2011.

Yang, F., Tan, J., Zhao, Q., Du, Z., He, K., Ma, Y., Duan, F., Chen, G., and Zhao, Q.: Characteristics of PM2.5 speciation in representative megacities and across China, Atmos. Chem. Phys., 11, 5207-5219, doi:10.5194/acp-11-5207-2011, 2011.
Yeung, M. C., Lee, B. P., Li, Y. J., and Chan, C. K.: Simultaneous HTDMA and HR-ToF-AMS measurements at the HKUST Supersite in Hong Kong in 2011, J. Geophys. Res.-Atmos., 119, 9864-9883, doi:10.1002/2013JD021146, 2014.

Yuan, Z. B., Yu, J. Z., Lau, A. K. H., Louie, P. K. K., and Fung, J. C. H.: Application of positive matrix factorization in estimating aerosol secondary organic carbon in Hong Kong and its relationship with secondary sulfate, Atmos. Chem. Phys., 6, 25-34, doi:10.5194/acp-6-25-2006, 2006.

Zhang, J. K., Sun, Y., Liu, Z. R., Ji, D. S., Hu, B., Liu, Q., and Wang, Y. S.: Characterization of submicron aerosols during a month of serious pollution in Beijing, 2013, Atmos. Chem. Phys., 14, 2887-2903, doi:10.5194/acp-14-2887-2014, 2014.

Zhang, Q., Jimenez, J. L., Canagaratna, M. R., Ulbrich, I. M., Ng, N. L., Worsnop, D. R., and Sun, Y. L.: Understanding atmospheric organic aerosols via factor analysis of aerosol mass spectrometry: a review, Anal. Bioanal. Chem., 401, 3045-3067, 2011.

Zhang, X. Y., Wang, Y. Q., Niu, T., Zhang, X. C., Gong, S. L., Zhang, Y. M., and Sun, J. Y.: Atmospheric aerosol compositions in China: spatial/temporal variability, chemical signature, regional haze distribution and comparisons with global aerosols, Atmos. Chem. Phys., 12, 779-799, doi:10.5194/acp12-779-2012, 2012.

Zhao, Y., Wang, S. X., Nielsen, C. P., Li, X. H., and Hao, J. M.: Establishment of a database of emission factors for atmospheric pollutants from Chinese coal-fired power plants, Atmos. Environ., 44, 1515-1523, 2010. 